\title{
An Analysis of Recreation User Perceptions: Crowding, Conflict, and Satisfaction at Diamond Lake, Oregon
}

Christoper D. Caplinger

West Virginia University

Follow this and additional works at: https://researchrepository.wvu.edu/etd

\section{Recommended Citation}

Caplinger, Christoper D., "An Analysis of Recreation User Perceptions: Crowding, Conflict, and Satisfaction at Diamond Lake, Oregon" (2013). Graduate Theses, Dissertations, and Problem Reports. 208.

https://researchrepository.wvu.edu/etd/208

This Thesis is protected by copyright and/or related rights. It has been brought to you by the The Research Repository @ WVU with permission from the rights-holder(s). You are free to use this Thesis in any way that is permitted by the copyright and related rights legislation that applies to your use. For other uses you must obtain permission from the rights-holder(s) directly, unless additional rights are indicated by a Creative Commons license in the record and/ or on the work itself. This Thesis has been accepted for inclusion in WVU Graduate Theses, Dissertations, and Problem Reports collection by an authorized administrator of The Research Repository @ WVU. For more information, please contact researchrepository@mail.wvu.edu. 


\title{
An Analysis of Recreation User Perceptions: Crowding, Conflict, and Satisfaction at Diamond Lake, Oregon
}

\author{
Christopher D. Caplinger
}

\author{
Thesis submitted to the \\ Davis College of Agriculture, Forestry and Consumer Sciences \\ at West Virginia University \\ in partial fulfillment of the requirements \\ for the degree of \\ Master of Science \\ in \\ Recreation, Parks and Tourism Resources \\ Robert C. Burns, Ph. D., Chair \\ Chad D. Pierskalla, Ph. D. \\ Dave Smaldone Ph. D. \\ Division of Forestry and Natural Resources \\ Morgantown, WV \\ 2013
}

Keywords: Crowding, Conflict, Satisfaction

Copyright 2013 Christopher D. Caplinger 


\author{
ABSTRACT \\ An Analysis of Recreation User Perceptions: \\ Crowding, Conflict, and Satisfaction at Diamond Lake, Oregon \\ Christopher D. Caplinger
}

This purpose of this study was to investigate visitor perceptions, particularly those related to crowding, conflict and satisfaction, within the context of Diamond Lake, while the relationship between these variables was also compared. The lake was analyzed both as a whole and across four separate zones which surround the lake. A thorough examination of visitor demographics and characteristics was included as well, in order to gain a clear understanding of the visitors who come to lake and provide additional insights into their perceptions.

This study was conducted over the summer of 2012 between May and August at Diamond Lake within the Umpqua National Forest. Surveys were conducted face-to-face, on-site with visitors using an iPad format for ease in compiling and analyzing results. In total, 772 surveys were collected during the three month survey period.

Results indicated that fishing was by far the predominant activity at Diamond Lake and that the majority of visitors were middle to older-aged, Caucasian males who were repeat visitors. Satisfaction was found to be consistently high among visitors, while conflict and crowding were found to be very low around the Lake. A regression analysis revealed that satisfaction items were a predictor of overall satisfaction. At the same time, conflict and crowding items were both found to be minor predictors of overall satisfaction. When compared across zones, it was found that satisfaction and conflict items were relatively consistent and there were no significant differences. However, crowding was found to be relatively higher in the North zone of the Lake, which generally sees the largest volume of visitors. 


\section{AKNOWLEDGEMENTS}

I would like to begin by acknowledging the love and support of all my family and friends throughout my time in school. To my roommates and close friends Jed Walkup, Tyler Wylie, Caleb Pugh and Trevor Caplinger: I can't thank you guys enough for putting up with me over the past two years. Through all the craziness of school and work, I've never worried about where I called home and where my friends were. Most importantly, I would like to thank my parents, Dave and Rose for being the best that anyone could ask for. Mom, thanks for always taking the time to listen and say a prayer on my behalf. I wouldn't be who I am today without you. Dad, through the ups and downs, thanks for being an example of the man I can only hope to be. Your sacrifices for your family and passion for the outdoors are what first inspired me to pursue a degree in natural resources. I love you both.

I would next like to thank the U.S. Forest Service personnel on the North Umpqua National Forest who made the work of this study possible. The assistance and cooperation provided by Bill Blackwell and Aaron Grimes in preparing and conducting this research deserve particular thanks. This project wouldn't have been possible without the time and insights they provided. I also appreciate the hard work and dedication of each of the surveyors who helped collect this data over the course of the summer.

During my time at West Virginia University I've also been truly blessed with the opportunity to work and study alongside so many other great students, faculty and professors in the Recreation, Parks and Tourism Resources program. In particular though, I would like to thank my officemates and NVUM colleagues Teri Chuprinko, Mike Ferguson, and Jen Highsmith. It's been a pleasure to work alongside each of you and I truly appreciate the support and sense of humor you've each had as we've worked together. I couldn't ask for better coworkers.

I would also like to say a special thanks to Dr. Chad Pierskalla and Dr. Dave Smaldone for being willing to be a part of my committee. Both were always willing to take time out of their busy schedules and offer input on this and many other projects.

Lastly, but certainly not least, I would like to thank Dr. Robert Burns. As my advisor and committee chair, no one has been more influential in my time as a Masters student at West Virginia University. I can't thank you enough for the tremendous opportunity you've extended to me by serving as my mentor. I've been truly humbled and challenged by the responsibilities you've entrusted to me. I consider it an honor to have called you my boss, teacher, and colleague.

Each of the people listed here deserves more credit than these few words suffice and I would also say thank you to the many other unnamed persons who've helped me each step of the way. You know who you are and I appreciate every one of you. 


\section{TABLE OF CONTENTS}

TABLE OF CONTENTS IV iv

LIST OF TABLES

CHAPTER 1- INTRODUCTION

$\mathrm{V}$

1

Statement of Research Questions 3

CHAPTER 2- LITERATURE REVIEW 4

Satisfaction Literature $\quad 5$

$\begin{array}{lr}\text { Conflict Literature } & 8\end{array}$

$\begin{array}{ll}\text { Crowding Literature } & 10\end{array}$

$\begin{array}{ll}\text { Conclusion } & 13\end{array}$

CHAPTER 3- METHODOLOGY 14

$\begin{array}{ll}\text { Study Area } & 14\end{array}$

Survey Instrument 16

$\begin{array}{ll}\text { Data Collection } & 17\end{array}$

Data Analysis $\quad 19$

$\begin{array}{ll}\text { Limitations } & 20\end{array}$

CHAPTER 4- RESULTS $\quad 22$

$\mathrm{R} 1$ : What are the characteristics of recreation users? $\quad 23$

$\mathrm{R} 2$ : What is the level of satisfaction among recreation users? 29

R3: What are users' perceptions of crowding and conflict at the lake? 31

R4: Which items are predictors of user satisfaction at Diamond Lake? Which 35 domain most influences satisfaction: Crowding or conflict?

R5: What differences in user perceptions of crowding, conflict and satisfaction 44 exist between locations?

CHAPTER 5- DISCUSSION \& CONCLUSIONS 46

R1: What are the characteristics of recreation users?

R2: What is the level of satisfaction among recreation users? $\quad 48$

R3: What are users' perceptions of crowding and conflict at the lake? 49

R4: Which items are predictors of user satisfaction at Diamond Lake? Which $\quad 51$ domain most influences satisfaction: Crowding or conflict?

R5: What differences in user perceptions of crowding, conflict and satisfaction 53 exist between locations?

Discussion $\quad 54$

Management Implications $\quad 58$

$\begin{array}{ll}\text { Conclusions } & 61\end{array}$

$\begin{array}{ll}\text { SURVEY INSTRUMENT } & 63\end{array}$

$\begin{array}{ll}\text { BIBLIOGRAPHY } & 67\end{array}$ 


\section{LIST OF TABLES AND FIGURES}

Figure 1. Map of Diamond Lake Zones $\quad 18$

Table 1. Survey Location $\quad 23$

Table 2. Visitor Demographics $\quad 24$

Table 3. Visitor Demographics continued 25

Table 4. Group Characteristics $\quad 26$

Table 5. Trip Characteristics $\quad 27$

Table 6. Activity Participation $\quad 28$

Table 7. Level of Satisfaction $\quad 29$

Table 8. Level of Agreement with Satisfaction Statements 30

Table 9. Level of Crowding $\quad 31$

Table 10. Time in Sight of Other Groups

Table 11. Expectation of Crowding $\quad 32$

Table 12. Level of Agreement with Crowding Statements 33

Table 13. Level of Agreement with Conflict Statements 34

Table 14. Correlation Matrix for Satisfaction Items 36

Table 15. Reliability Analysis for Satisfaction Items 36

Table 16. Correlation Matrix for Crowding Items $\quad 37$

Table 17. Reliability Analysis for Crowding Items 38

Table 18. Correlation Matrix for Conflict Items $\quad 39$

Table 19. Reliability Analysis for Conflict Items $\quad 39$

Table 20. Regression Analysis of Satisfaction Items as Indicators of Satisfaction 40

Table 21. Regression Analysis of Crowding Items as Indicators of Satisfaction 41

Table 22. Regression Analysis of Conflict Items as Indicators of Satisfaction 42

Figure 2. Relationship of Satisfaction, Crowding, \& Conflict to Overall 43

Satisfaction

Table 23. Comparison of Crowding, Conflict \& Satisfaction Means Across 45

Survey Locations 


\section{CHAPTER 1}

\section{INTRODUCTION}

In recent years, one of the greatest issues facing law-makers and government entities has been how to become more efficient. With declining budgets and an ever increasing quantity of regulations that they are forced to abide by and operate within, agencies like the U.S. Forest Service have become gradually more and more stretched to manage effectively under these constraints. The Forest Service has especially been impacted by budget cuts that have forced the agency to reallocate funding, as well as cut positions and programs (USDA Forest Service, 2007). Coupled with the fact that the Forest Service expects an increase in forest use, this creates a difficult situation for managers (Gaydos, 2008; Manning, 2011). As a result, the resources at the disposal of the Forest Service must be distributed pragmatically so as to be most effectual.

At the same time, the role of Forest Service managers is evolving; it is becoming less focused on solely ecological concerns and instead looks to balance both social and ecological issues. With that said, both of these aspects to natural resource management are heavily impacted by the other. For example, people come to natural settings (e.g. National Forests) primarily to experience the outdoors and nature (Gaydos, 2008; Shrestha et al., 2008). Likewise, they cause impacts on the environment simply by virtue of being there and participating in activities (Lohman, 2010). Not only is the National Forest Service mandated to provide recreation opportunities by the federal government (Multiple Use Sustained Yield Act, 1960), but it also presents a great opportunity for the agency. Recreation activities attract an estimated 200 million visitors to forest lands per year, which contributes over 11 billion dollars a year to the economy 
(USDA Forest Service, 2007). With that said, it is of vital importance that managers are aware of and active in overseeing recreational activities in these areas.

One of the ways in which these challenges can be met is by having access to better information concerning these resources and the people who use them. With detailed information concerning visitors, their preferences, perceptions, and satisfaction related to their forest experience, managers can learn a plethora of useful details. Things like where they go, what they are expecting, which service quality variables are most important to them, etc. all allow the Forest Service to provide much better quality to the general public, as well as allocate resources more effectively (Kocis et al., 2003). A good example of this need can be found in the Umpqua National Forest, surrounding Diamond Lake; where managers are monitoring the issuing of permits to outfitters and guides who operate within the forest. While private use is not regulated, permits are issued to commercial entities to regulate the volume of people that a given guide service can take on any one day, thereby helping managers control recreation use in the forest as well as the associated impacts (Kocis et al., 2003; Lohman, 2010). At this time, managers currently only regulate rafting use in the forest along the Umpqua River, yet are beginning to explore the possibility of issuing special-use permits to outfitter guides for activities like mountain biking and fishing.

With this in mind, the purpose of this study was to firstly report on the characteristics of visitors at Diamond Lake so as to provide additional insight into the overall results. Secondly and most importantly, this study specifically examines the perceptions of visitors to Diamond Lake regarding crowding, conflict and associated user satisfaction. This will give managers vital information concerning use at the lake. From a social perspective, this offers a much more accurate perspective of the actual conditions in the forest. For example, what are the types of 
experiences that people are looking for at Diamond Lake or what are the chief problems they recognize that currently need to be addressed and how are these variables related? The answers to questions like this are significant in the decisions of managers to decrease or increase the number of permits in association with the given need, as well as in making future management decisions.

\section{Research Questions}

R1: What are the characteristics of recreation users?

R2: What is the level of satisfaction among recreation users?

R3: What are users' perceptions of crowding and conflict at the lake?

R4: Which items are predictors of user satisfaction at Diamond Lake? Which domain most influences satisfaction: Crowding or conflict?

R5: What differences in user perceptions of crowding, conflict and satisfaction exist between locations? 


\section{CHAPTER 2 \\ LITERATURE REVIEW}

The purpose of this section is to provide background information on the topics of crowding, conflict, and satisfaction. Relevant literature is summarized and examined so as to establish the current status of research in these areas. In the same way, these concepts are defined in order that they might be better understood and examined within the context of Diamond Lake, Oregon.

Historically, the need to protect and preserve the natural environment in response to overexploitation was the driving force behind the establishment and practice of natural resource management. However, in the post-World War II boom, the average American found they had increasing amounts of leisure time and disposal income. Consequently, parks and public lands saw increasing recreation use and demand among the general public (Manning, 2011). As already mentioned, recreation use has an impact on the natural settings in which it takes place (Lohman, 2010), thereby necessitating its consideration by managers (Multiple Use Sustained Yield Act, 1960).

With this in mind, recreation as a field of study is itself relatively young and unique from many other schools of thought in natural resources. It must examine both biological and social factors and seeks to integrate the two into practical management principles. Likewise, interest in human dynamics has grown substantially in recent years, reflecting the increasing drive to balance social and ecological concerns (Manning, 2011). This study focuses on the social aspect, particularly the constructs of crowding, conflict, and satisfaction. 


\section{$\underline{\text { Satisfaction Literature }}$}

Satisfaction has long been a variable which managers in various sectors have chosen to examine as they seek to serve customers. While closely associated with the concept of quality (Manning, 2011), satisfaction itself is born out of expectancy theory, which holds that consumers will engage in a particular set of activities so as to meet needs or desired outcomes (Vroom, 1964). The satisfaction of those users or customers is thereby determined by how closely their expectation of service is realized through the use of that service (Bultena \& Klessig, 1969). Therefore, satisfaction is a measurement of the degree to which consumer goals are achieved through the use of a product or service (Oliver, 1997; Zeithaml \& Bitner, 1996). As the modern markets have shifted to become more service-based, this has become an increasingly important concept to businesses, managers, and researchers (Manning, 2011).

Wagar (1966) first introduced the concept of satisfaction to the field of recreation management by arguing for its significance as a primary social criterion in recreation research. Since then, the standard of recreation management success with regard to social aspects has largely come to be defined by the satisfaction of visitors and users (Bultena \& Klessig, 1969). Many public land administrators now focus on maximizing the satisfaction or minimizing the dissatisfaction of visitors and consider it to be a key factor in their decisions (Burns, 2000). As asserted by Lime and Stankey (1971), the foremost goal of most recreation management is to maximize recreationists' satisfaction while acknowledging managerial constraints.

Accordingly, the federal government made satisfaction a specific management guideline with the passage of the Government Performance and Results Act (1993). Various government agencies in natural resource management have since implemented monitoring programs, designed to provide managers with accurate data on visitor satisfaction. For example, the 
U.S.D.A. Forest Service has been collecting extensive visitor data through the National Visitor Use Monitoring Program (NVUM) in National Forests since the mid 90's (Kocis et al., 2003). There are a number of factors which contribute to overall satisfaction and make it a difficult construct to measure; things like the type of visitor group, location, weather, etc. all contribute to user satisfaction (Borrie and Birzell, 2001). Satisfaction can also vary based upon the type of experience that is expected from a particular resource (Demir et al., 2010). Consequently, Graefe and Fedler (1986) suggest that it is important to utilize multiple scales and attributes in determining visitor satisfaction levels. As Manning (2011) points out, a single measure of overall satisfaction can be a misleading gauge of true satisfaction in recreation settings. An overall level is certainly paramount in evaluating visitor satisfaction, but should be backed by measures of various variables which individually contribute to the overall value, thereby ensuring the validity of any findings (Manning, 2011).

Many of the frameworks used by recreation managers to evaluate satisfaction on public lands are based in the field of marketing and the concept of service quality. Service quality is a measure of the customer's overall perception of a product or service worth (Gaydos, 2008; Stankey et al. 1985). Service quality is noted as being the foremost indicator of customer satisfaction (Lee, Graefe, and Burns, 2004).

Service quality itself is difficult to measure because of three key characteristics: intangibility, heterogeneity, and inseparability of production and consumption. In other words, services differ from other products one might purchase in that they are actions and not physical items and therefore the very act of producing them is simultaneous with their "consumption." Likewise, they are not uniform; no two services rendered are going to be identical (Gaydos, 2008; Stankey et al. 1985). As a result, one of the most common methods of measuring service 
quality is known as the Gaps model (Parasuraman et al., 1985). This model was based on the SERVQUAL model, which compares twenty-two items related to quality of service and had been previously used in other fields as a measurement tool. SERVQUAL was found to be somewhat cumbersome, causing Parasuraman et al. (1988) to refine it from ten determinants to only five, described below:

Reliability: $\quad$ The ability to perform the promised service dependably and
accurately.
Assurance: $\quad \begin{aligned} & \text { The knowledge and courtesy of employees and their ability to } \\ & \text { inspire trust and confidence. }\end{aligned}$

Tangibles: $\quad$ Physical facilities, equipment, and appearance of personnel.

Empathy: The caring individualized attention that you provide your customer.

Responsiveness: The willingness to help customers and provide prompt services.

Refining the SERVQUAL model allowed Parasuraman et al. (1988) to discover gaps which impacted perceptions of service quality. These gaps consequently provided a means of understanding why customers might have perceptions of low service quality, not offered by SERVQUAL. Whereas SERVQUAL was unwieldy and hard to conceptualize, the Gaps model was developed as a simplified model of service quality and demonstrated the difference between the expectations of customers against their perception of what is actually delivered (Gaydos, 2008; Parasuraman et al., 1985; Parasuraman et al. 1988). Parasuraman et al. (1988) noted that the Gaps model complements SERVQUAL and suggested they be used concurrently for optimal results. Parasuraman et al. (1988) identified four primary gaps: 
Gap 1: Results from a difference between what customers expect and what managers perceive these expectations to be.

Gap 2: Results from a difference between management perceptions of consumer expectations and service quality specifications.

Gap 3: Results from a difference between service quality specification and the service which is actually delivered.

Gap 4: $\quad$ Results from the difference between service delivery and what is communicated about the service to the consumers.

Based on the work of Parasuraman et al. (1988), MacKay and Crompton (1988) adapted the SERVQUAL model specifically to the field of outdoor recreation. Their model incorporated twelve of the original SERVQUAL items with an additional thirteen items they chose, resulting in a hybrid model known as RECQUAL. As the first researchers to apply this method to recreation service quality, MacKay and Crompton found that service quality is the connection between consumers' expectations of service and their perceptions of that service. Later, Cronin and Taylor (1992) proposed that expectations were an unnecessary component to the SERVQUAL model. This contrasting approach to Parasuraman et al.'s model (1988) focused instead on performance-only measures and became known as SERVPERF (Cronin and Taylor, 1992). It was with these models in mind, that Burns (2000) compared the differing paradigms to determine their effectiveness. By employing nineteen individual indicators of satisfaction that fell into four different domains (facilities, services, information, and recreation experiences), Burns (2000) confirmed that there was indeed a significant difference between the ability of the two models to predict overall satisfaction. In fact, Burns (2000) found that performance-only measures were two to three times better indicators of overall satisfaction than expectationperformance measures. 


\section{$\underline{\text { Conflict Literature }}$}

Conflict is certainly a subject not exclusive to the field of recreation and can be examined through a variety of paradigms. In terms of recreation use though, Jacob and Schreyer (1980) specifically define conflict as "goal interference attributed to another's behavior." This is an important construct as research has established the relationship between conflict and satisfaction among recreationists (Manning, 2011). Conflict is based upon and requires social contact, both direct and indirect. Direct contact implies active interactions, whereas indirect contact refers to passive interactions (Jacob and Schreyer, 1980). Research has suggested that there is a direct correlation between the amount of interactions and subsequent conflict between outdoor users (Cole and Hall, 2009). Similarly, Jacob and Schreyer's theoretical model (1980) proposed that all conflict can be attributed to four major factors:

Activity style- Refers to the various personal meanings attributed to recreational activities.

Resource specificity- The significance attached to using a specific recreation resource for a given recreational experience.

Mode of experience- Infers the varying expectations of how the natural environment will be perceived.

Lifestyle tolerance- This is the tendency to accept or reject lifestyles different from one's own.

While conflict may arise from any one of these domains as users compete for space and access to resources, Jackson and Wong (1982) note that this is a direct result of the goals of individuals' not being realized due to the intrusion of others. In fact, many times recreationrelated conflict is directed one way and focused from one particular user group towards another; 
the latter typically being either tolerant or indifferent to their counterparts' activities.

Unsurprisingly, this can create an atmosphere of animosity and distrust between user groups, leading to further misunderstanding and division (Jackson and Wong, 1982). Rather than identify clear offenders, the goal of consequent conflict mediation and management is often to simply foster understanding and a framework for making decisions, which stakeholders recognize as legitimate (Irland, 1975).

More recent research suggests that visitors who are more dependent upon a place or resource for the quality of their experience are typically more sensitive to goal interference by others (Gibbons \& Ruddell, 1995). In other words, when recreationists rely upon a specific site to accomplish their recreation goals, they are more likely to experience conflict with others who might keep them from accomplishing these goals (Wang \& Chang, 2010). However, it has also been found that water-based recreationists are typically more sensitive to conflict depending on their tolerance of other activities (Adelman et al. 1982). These findings have also been corroborated by more recent research concerning conflict specific to water-based recreation (Wang \& Dawson, 2005). In their study of the watercraft use along the Great Lakes shoreline in New York, Wang and Dawson (2005) found that mode of experience and lifestyle tolerance were the two greatest predictors of conflict among recreationists and landowners.

\section{Crowding Literature}

Crowding is defined by Stokols (1972) as the psychological stress which stems from an individual's demand for space exceeding the supply. As applied to recreation and according to Schmidt and Keating's social interference theory (1979), crowding is defined by actual or perceived levels of use exceeding those levels which an individual might consider acceptable. 
With that in mind, crowding is by very nature arbitrary — that is, it is based upon the subjective perceptions and attitudes of individuals. These feelings result primarily from exposure to experiences and information about their environment that these individuals take in; be it either physical or intuitive. A person then takes that data and responds according to their own interpretation, otherwise known as perceptions (Lime and Stankey, 1971; Peden \& Schuster, 2008).

As it relates to recreation, the concept of perceived crowding is based on the idea that all wild lands and natural resources have a carrying capacity. Carrying capacity itself is defined as the threshold at which growth or further use of a resource is constrained by environmental factors. Most simply put, carrying capacity is the highest level of visitor use that can be accommodated in a given area (Manning, 1999; Manning, 2011; Odum, 1959). This idea has long been central to many natural resource disciplines and has been applied for example, to wildlife and range management (Manning, 2011). Wagar (1946) was the first to acknowledge that humans, like wildlife, have a limited capacity for interactions in natural settings. Crowding was first formally recognized by Wagar (1964) when upon a review of carrying capacity, he demonstrated the relationship between user density and the increasing inability of users to achieve their desired outcomes. He concluded that "when too many people use the same area, some traditional wild land values are lost." More specifically, this illustrated the correlation between crowding and the degradation of user satisfaction (Manning, 2011; Wagar, 1964).

To manage public lands accordingly, managers and researchers have turned to LAC (Stankey et al., 1985) and VERP (USDI National Park Service, 1993). The Limits of Acceptable Change (or LAC) and Visitor Experience \& Resource Protection (or VERP) are simply frameworks for monitoring and addressing impacts on public lands (Manning, 2011; Stankey et 
al., 1985; USDI National Park Service, 1993). As managers seek to deal with these impacts under the LAC and VERP guidelines, crowding has come to be recognized as the single greatest indicator of social carrying capacity on public lands (Manning, 1999). Therefore, understanding visitor perceptions of crowding is a critical component to identifying the social carrying capacity of public lands and areas (Manning, 1999; Manning and Lime, 1996).

It must be emphasized that perceived crowding is not merely a matter of the actual user density. Rather, there are numerous factors which contribute to a person's feelings of perceived crowding (Manning, 2003). As already alluded to, these can come from stimuli in their immediate environment (i.e. the actual use-level), but they can also be contingent upon one's expected and preferred use-levels (Desor, 1972; Kuentzel and Heberlein, 1992; Stokols, 1972). For example, in a study by Stankey (1973) it was found that users who came to Wilderness areas expecting solitude as part of their experience were much more sensitive to the presence of others. In a study on camping and boating at Apostle Islands National Lakeshore in WI; Vaske, Donnelly, and Heberlein (1980) found that there were in fact differences between first time visitors and repeat visitors in terms of perceived crowding. Schreyer, Lime, and Williams (1984) note that recreation users with higher levels of experience are typically more sensitive to crowding.

In response to crowding, visitors will often employ various coping techniques like displacement or rationalization (Desor, 1972; Schmidt and Keating, 1979). It has been well documented that recreation users do this in a variety of settings. Schindler and Shelby (1995) surveyed boaters from the Rogue River in Oregon, first in 1977 and then again in 1991. Their results revealed that even as use-levels increased along the river the boaters' perceptions of crowding had remained constant, suggesting that over time the boaters had shifted their 
expectations from a low-use to a high-use experience in response to changes. Another study done in Acadia National Park, found that while the level of perceived crowding among park visitors was low, visitors at sites considered to be low-use felt more crowded than visitors to high-use sites. Likewise, it is was the low-use site users who tended to be return visitors, suggesting that returning park visitors were being displaced in order to avoid more congested areas (Anderson et al., 2008).

\section{$\underline{\text { Conclusion }}$}

In light of the literature, it can be concluded that the domains of satisfaction, conflict and crowding are indeed interrelated; each contributing in part to the associated levels of the other. Likewise, they are significant to resource managers in that they are highly indicative of the social conditions in a location. With this in mind, this study specifically sought to examine the relationship between these constructs, build upon existing data, and serve as a case study of general recreation use at Diamond Lake, Oregon. 


\section{CHAPTER 3 METHODOLOGY}

This section will detail the methods for compiling datum at Diamond Lake, as well as the procedures by which it was analyzed. This study was conducted as part of a larger study by West Virginia University and the USDA Forest Service examining recreation use along the Route 138 corridor of the Umpqua National Forest. It was also completed in association with the research carried out by the Forest Service's National Visitor Use Monitoring Program, also referred to as NVUM.

\section{Study Area}

Diamond Lake is situated in the eastern side of the North Umpqua National Forest with the forest itself located within the Pacific Northwest Region of the USDA Forest Service, otherwise known as Region 6. Region 6 encompasses the states of Oregon and Washington and is comprised of 19 national forests, two volcanic monuments, one national grassland, and one national scenic area. The Umpqua National Forest is located in the Cascade Mountains of southwestern Oregon and covers 984,602 acres of designated lands; including the Boulder Creek, Rogue-Umpqua Divide, and Mt. Thielsen Wilderness areas (USDA Forest Service, 2012).

Deriving its name from the Indian word for "thundering waters," the forest has long been known for the Umpqua River and many lakes which lie within its borders. Officially set aside as a national forest in March of 1907, the Umpqua has since attracted forest recreation use of all varieties. Primarily noted for the fishing at areas like Diamond Lake and along the Umpqua River, the scenic beauty of this forest also appeals to hikers, mountain bikers, boaters, rafters and many others (USDA Forest Service, 2012). With the Route 138 Rogue-Umpqua Scenic Byway running through the heart of the forest and connecting to other popular locations such as Crater 
Lake National Park, the forest is a popular area for recreationists. Likewise, the forest is readily accessible from Interstate 5 through the cities of Roseburg or Medford (Gaydos, 2008).

Chief among the lakes in the Umpqua National Forest is Diamond Lake, although it is many times overshadowed by Crater Lake which lies only minutes away. Diamond Lake is seen primarily as a fishing destination and is home to the privately operated Diamond Lake Resort and numerous Forest Service campgrounds which surround the lake (USDA Forest Service, 2012). Sitting beneath the backdrop of Mt. Thielsen and Mt. Bailey, Diamond Lake is easily the most popular recreation area within the Umpqua National Forest.

Since the lake was first stocked with trout in 1910, angling has thrived at the lake. However, it was in 1946 that fishing at Diamond Lake was threatened by the inadvertent introduction of the invasive, exotic species Gila Bicolor Pectinifer or Tui Chub. The Tui Chub was quickly able to out-compete trout, as they depended upon the same food sources and are capable of faster reproduction (Gaydos, 2008). In 1954, it was decided that the Tui Chub would be eradicated by means of draining and poisoning the lake with a substance known as rotenone. This was successful and the lake once again enjoyed a reputation as a high quality fishing location. It was not until the mid-nineties that the quality of the lake had once again declined and the Tui Chub were rediscovered there. In 2006, the lake was again closed, drained, and poisoned to remove the Tui Chub. This treatment was just as successful as the first and Diamond Lake experienced a dramatic recovery in the years that followed (Gaydos, 2008). Today Diamond Lake continues to be one of the most popular fishing sites in Oregon (USDA Forest Service, 2012). 


\section{Survey Instrument}

As mentioned earlier, this study was conducted as part of a larger project, studying recreation use in the northern Umpqua National Forest along Route 138. This comprehensive study utilized iPads to collect data. Actual interviews were conducted using both iPads and corresponding paper surveys as needed; paper surveys were later entered into iPads for consistency and expediency. The survey instrument for the Diamond Lake study included elements common to all areas in the forest, as well as portions devoted to gauging specific issues at Diamond Lake. As this particular study was designed to measure the levels of perceived crowding, conflict and satisfaction of recreation at Diamond Lake, the survey instrument included components which focus on measuring these constructs.

Just as in the study by Gaydos (2008), respondents were asked to rate their overall satisfaction of a on a ten-point scale, with " 1 " being worst and "10" being best. This was also consistent with other studies on recreation satisfaction (Burns, 2000; Demir et al., 2010; Manning, 2011; Mestrovic III, 2011), allowing for comparison between this study and other data. For the purposes of measuring crowding, respondents were asked questions related to both their expectations and actual perceptions of crowding at the lake. More specifically they were asked to share the percentages of time that they were in sight of other groups, as well as what they would consider to be an acceptable percentage of time to be in sight of other groups. Visitors were then asked how the number of people they saw compared with what they expected to see. This was measured on a 6-point scale, where " 1 " is a lot less than expected, "5" is a lot more than expected, and " 6 " was no expectations. Overall feelings of crowding were also measured on a nine-point scale, with " 1 " being not at all crowded and "9" being extremely crowded. All of 
these measures were modeled after previous crowding research (Anderson et al., 2008;

Chuprinko, 2012; Mestrovic III, 2011).

Lastly, visitors were also asked to respond to a battery of statements which included satisfaction, crowding, and conflict related items. These were measured on a were on a five-point Likert scale; options included strongly "agree," "agree," "neutral," "disagree," and "strongly disagree." In total, there were four satisfaction items, three crowding items, and three conflict items included in this set of statement-questions which were taken from previous studies (Chuprinko, 2012; Gaydos, 2008; Mestrovic III, 2011).

\section{$\underline{\text { Data Collection }}$}

Data was collected for the purposes of this study through face-to-face interviews of recreationists around Diamond Lake. Responses were collected and stored on iPads, which were then uploaded to the internet to be downloaded directly into SPSS for analysis at a later date. These interviews were conducted from mid-May through August of 2012. With a perimeter of nearly five miles, the lake was divided into four distinct geographic zones; the east, south, west and north shores (see Map of Diamond Lake Zones, Pg. 62). The eastern, southern, and western shores all consist primarily of campgrounds, while Diamond Lake Resort is located on the northern shore. All survey sites were divided into one of these areas in accordance with the previous research which this study was modeled after (Gaydos, 2008). Surveys were conducted on site, within these four separate zones, at predetermined times and locations. Sampling days were divided equally amongst the four zones and surveyors collected data over 6-hour shifts, starting at $10 \mathrm{am}$ and ending at $4 \mathrm{pm}$. 
Figure 1. Map of Diamond Lake Zones

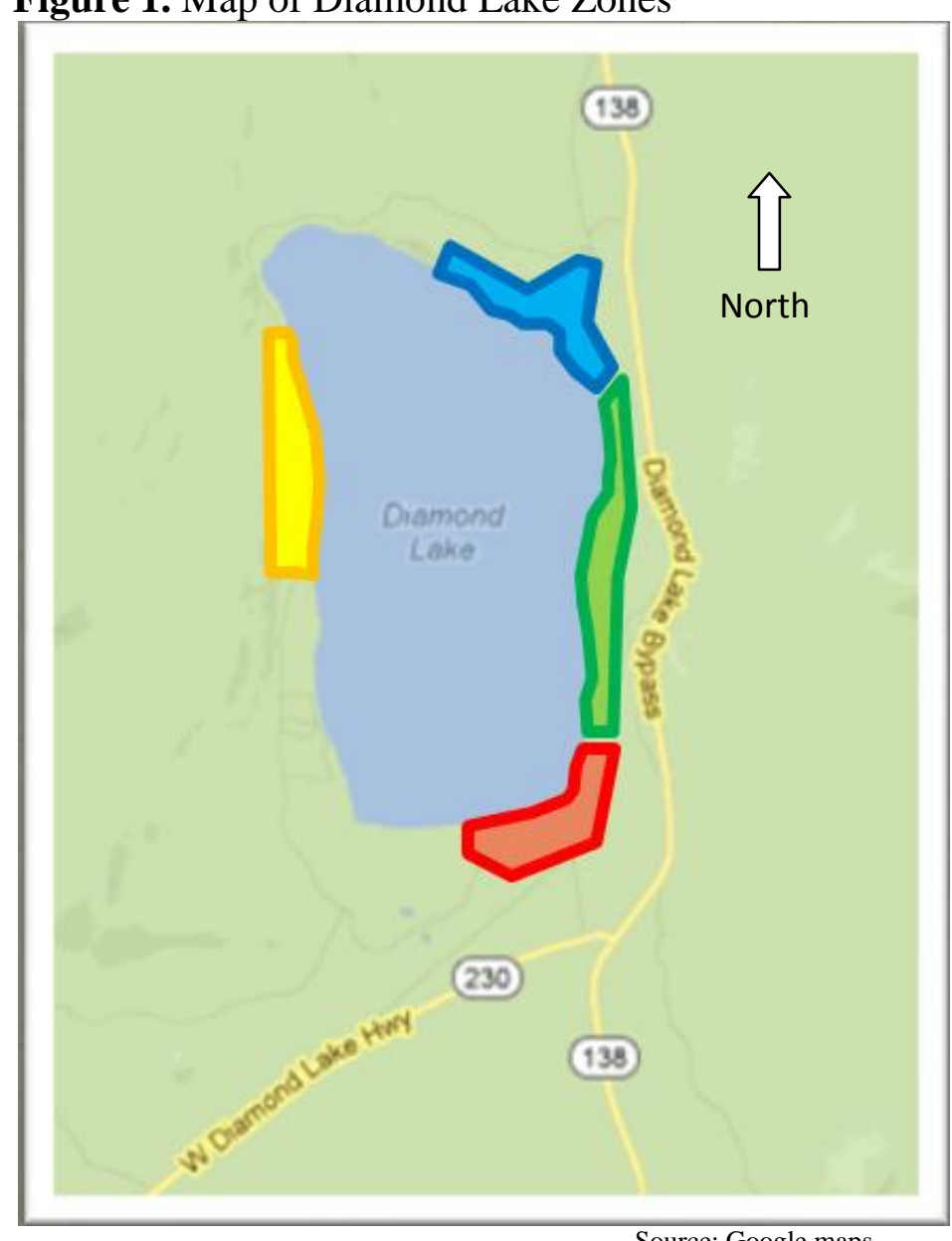

Source: Google maps

Once onsite, interviewers were able to move around as needed and approach groups within that particular zone, using a convenience method. All willing individuals in each group were asked to complete the survey. Respondents were asked to be over the age of 16 and any refusals were also recorded. If interviewers were unable to initiate a reasonable number of interviews at a certain point over a given hour, they were encouraged to move to a new location in search of potential interviewees. Surveyors primarily used the iPads for these interviews; however, paper copies of the survey were also distributed to larger groups and entered later. 


\section{$\underline{\text { Data Analysis }}$}

All the data that were collected at Diamond Lake was compiled in iPad format, using iSurvey software. Responses were then downloaded directly for analysis using Statistical Packages for the Social Science Version 20. The significance level for each statistical test was set at 0.05 . The previously stated research questions were tested as follows.

\section{R1: What are the characteristics of recreation users?}

To gain an accurate profile of use and the type of visitors coming to Diamond Lake they were examined on the basis of gender, age group composition, and first-time vs. repeat visit. Basic descriptive statistics were reported, including frequencies and valid percentages.

\section{R2: What is the level of satisfaction among recreation users?}

Under this question the basic frequencies, means, and valid percentages of items related to satisfaction are reported.

\section{R3: What are users' perceptions of crowding and conflict at the lake?}

Both the constructs of crowding and conflict were compared separately in this question. Just like satisfaction, crowding and conflict items were both examined using frequencies and means, and valid percentages.

\section{R4: Which items are predictors of user satisfaction at Diamond Lake? Which domain most influences satisfaction: Crowding or conflict?}

Aside from the summarized frequencies and means of individual satisfaction, crowding and conflict items, each domain was tested using a correlation matrix and reliability analysis. Likewise, three separate regression analyses are used to compare satisfaction, crowding, and conflict items to overall satisfaction and evaluate their relationship. 


\section{R5: What differences in user perceptions of crowding, conflict and satisfaction exist between locations?}

In addition to the frequencies and respective means or valid percentages of items, the four predetermined zones surrounding Diamond Lake (North, South, East, \& West) were compared in this question. A one-way analysis of variation (ANOVA) was used where the significance level is set at $0.05(\alpha=0.05)$ and with a $95 \%$ confidence interval to specifically compare these zones and their associated levels of crowding, conflict, and satisfaction.

\section{$\underline{\text { Limitations }}$}

The weather conditions at Diamond Lake itself made it somewhat problematic to try and schedule survey days very far ahead of time. At around 4,500 feet above sea level, conditions are wintery well into June. Roads and facilities (particularly campgrounds on the eastern, southern, and western shores) are opened only after the Forest Service has cleared away snow and debris. While a schedule was planned out at the beginning of the study, this had to be adapted and changed numerous times to accommodate the changing and sometimes erratic weather conditions of the area.

Another important constraint of this study is that survey days were not randomly selected. Due to scheduling and time limitations, surveyors were assigned days on which the largest volume of visitors was expected, thereby procuring the highest possible number of cases. With this in mind, the number of surveys collected is not necessarily an accurate representation of the use level at the Lake, but rather the characteristics of visitors and their perceptions.

It should also be noted that the 2008 Gaydos study, which many parts of this study were modeled upon, specifically focused on assessing service quality indicators at Diamond Lake as 
they related to predicting satisfaction of customers. While this allows for a reasonable comparison of satisfaction then versus now, it makes in-depth evaluation of conflict and crowding levels at that time more difficult to assess. Gaydos evaluated these to an extent in several questions; however it is difficult at best to extrapolate an accurate picture of crowding and conflict from these alone. Accordingly, the emphasis of this study is distinct in that it seeks to provide a clear representation of the recreation users and their perceptions over the summer of 2012. 


\section{CHAPTER 4}

RESULTS

The following chapter describes the results of the data collection effort at Diamond Lake, as well as drawing comparisons across variables. In accordance with research questions, the demographic composition of visitors is detailed first, including the trip and group characteristics. This is followed by an examination of the users' satisfaction, in addition to their perceptions of crowding and conflict. Lastly, this chapter compares trends in characteristics and perceptions across locations. Frequencies, valid percentages, means and other comparisons were compiled into tables from the collected data and presented in the body of this chapter.

The survey locations for this study were divided up into four contiguous zones, surrounding the lake. These were designated according to their geographic location in relation to the lake and a combined total of 772 surveys were collected within all four (Table 1). In clockwise order, the first was the North zone. This area included Diamond Lake Resort, the boat docks, and boat ramp. This was a relatively high-use area and 221 of the surveys (28.6\%) were collected in this zone. Next was the East zone which was predominantly made up of the Diamond Lake Campground, but also included the visitor center. With 256 surveys (33.2\%) more surveys were collected here than at any other zone. The South zone includes such sites as Broken Arrow Campground and the South Shore boat ramps and picnic area. A total of 188 surveys were collected here (24.4\%). Lastly, the West zone accounted for 107 surveys (13.9\%) and sites like Thielsen View Campground and boat ramp could be found here. 
Table 1. Survey Location

\begin{tabular}{|c|c|c|}
\hline \multicolumn{2}{|c|}{ Frequency } & Percent \\
\hline Zone & 256 & 33.2 \\
\hline East & 221 & 28.6 \\
\hline North & 188 & 24.4 \\
\hline South & 107 & 13.9 \\
\hline West & 772 & 100.0 \\
\hline Total &
\end{tabular}

\section{R1: What are the characteristics of recreation users?}

In order to gain an accurate perspective on the types of visitors at Diamond Lake, respondents were asked to answer numerous questions regarding their socio-demographic and trip characteristics, beginning with their gender and age (Table 2). Results revealed that males made up the majority of visitors to Diamond Lake with 59.2\%, compared to $40.8 \%$ identifying themselves as female. The average age of respondents was relatively high at exactly 48 years old. In the same way, the distribution of visitors increased markedly with age; nearly half of the respondents $(47.1 \%)$ were over the age of 50.

Respondents were also asked to share about their level of education, income, and nationality (Table 2). Results indicated that respondents were moderately to well-educated and over half (52.6\%) possessed a Bachelors degree or higher. The largest portion of visitors (40.2\%) reported that their household income was between $\$ 50,000$ and $\$ 99,000$ per year. Very few of the visitors said that they weren't U.S. citizens (2.5\%). 
Table 2. Visitor Demographics

\begin{tabular}{|c|c|c|}
\hline & Frequency & Percent \\
\hline \multicolumn{3}{|l|}{ Gender } \\
\hline Male & 451 & 59.2 \\
\hline Female & 311 & 40.8 \\
\hline \multicolumn{3}{|l|}{ Age } \\
\hline $16-20$ & 30 & 4.0 \\
\hline $21-30$ & 94 & 12.5 \\
\hline $31-40$ & 140 & 18.6 \\
\hline $41-50$ & 135 & 17.9 \\
\hline $51-60$ & 161 & 21.4 \\
\hline $61-70$ & 153 & 20.3 \\
\hline Over 70 & 41 & 5.4 \\
\hline Mean Age & \multicolumn{2}{|c|}{48.00} \\
\hline \multicolumn{3}{|l|}{ U.S. Resident? } \\
\hline Yes & 751 & 97.5 \\
\hline No & 19 & 2.5 \\
\hline \multicolumn{3}{|l|}{ Level of Education } \\
\hline High School or less & 148 & 19.9 \\
\hline Technical school/2 year colleg & 204 & 27.5 \\
\hline Bachelor's Degree & 278 & 37.5 \\
\hline Master's Degree & 95 & 12.8 \\
\hline Ph. D./Professional Degree & 17 & 2.3 \\
\hline \multicolumn{3}{|l|}{ Annual Household Income } \\
\hline$\$ 25 \mathrm{k}$ or less & 59 & 8.3 \\
\hline$\$ 25 \mathrm{k}-\mathrm{-} \$ 49 \mathrm{k}$ & 105 & 14.8 \\
\hline$\$ 50 \mathrm{k}--\$ 99 \mathrm{k}$ & 286 & 40.2 \\
\hline$\$ 100 \mathrm{k}-\mathrm{-} \$ 149 \mathrm{k}$ & 130 & 18.3 \\
\hline$\$ 150 \mathrm{k}--\$ 199 \mathrm{k}$ & 23 & 3.2 \\
\hline$\$ 200 \mathrm{k}$ or over & 20 & 2.8 \\
\hline Don't know & 88 & 12.4 \\
\hline
\end{tabular}

Visitors were asked to indicate the race(s) and/or ethnicity with which they most identified (Table 3). In large part, the sample group identified itself as a white or Caucasian (97.4\%); with American Indian or Alaska Native (3.8\%), Black or African American (2.0\%), 
Japanese (1.6\%), and Korean (1.1\%) represented too. Similarly, a small portion of visitors $(3.1 \% \%)$ said that they were of Hispanic, Latino or Spanish origin, as well.

Table 3. Visitor Demographics continued

\begin{tabular}{|l|c|c|}
\hline & Frequency & Percent \\
\hline \multicolumn{2}{|l|}{ Hispanic, Latino or Spanish origin? } & 3.1 \\
\hline Yes & 23 & 96.9 \\
\hline No & 725 & \\
\hline \multicolumn{2}{|l|}{} \\
\hline Race & 726 & 97.4 \\
\hline White & 15 & 2.0 \\
\hline Black or African American & 28 & 3.8 \\
\hline American Indian or Alaska & 5 & 0.7 \\
Native & 12 & 1.6 \\
\hline Asian Indian & 6 & 0.8 \\
\hline Japanese & 6 & 0.8 \\
\hline Native Hawaiian & 8 & 1.1 \\
\hline Chinese & 6 & 0.8 \\
\hline Korean & 3 & 0.4 \\
\hline Filipino & 5 & 0.7 \\
\hline Vietnamese & 8 & 1.1 \\
\hline Samoan & & \\
\hline Other Asian or Pacific & & \\
Islander & & \\
\hline
\end{tabular}

With regard to group characteristics (Table 4), the average group contained 4 adults $($ mean $=4.4$ adults $)$ and 1 child (mean $=1.48$ children $)$. The average number of vehicles per group was two (mean $=2.06$ ), while of those who answered, there was an average of one RV $($ mean $=0.56)$ and one trailer per group $($ mean $=0.91)$. Nearly half of the visitors to Diamond Lake $(45.2 \%)$ came with their family, while over a quarter $(30.4 \%)$ said that they came with friends and family. Only $17.4 \%$ said they were with friends and $6.1 \%$ said that they were alone. There were almost no "other" $(0.3 \%)$ or organized groups $(0.6 \%)$. 
Table 4. Group Characteristics

\begin{tabular}{|c|c|c|}
\hline & Frequency & Percent/Mean \\
\hline \multicolumn{3}{|l|}{ Mean group size } \\
\hline Adults per group & 764 & 4.40 \\
\hline Children per group & 636 & 1.48 \\
\hline \multicolumn{3}{|l|}{ Mean number of vehicles } \\
\hline $\begin{array}{l}\text { Cars/trucks/motorcycles per } \\
\text { group }\end{array}$ & 760 & 2.06 \\
\hline RV's per group & 589 & 0.56 \\
\hline Trailers per group & 647 & 0.91 \\
\hline \multicolumn{3}{|l|}{ Group composition } \\
\hline Alone & 47 & 6.1 \\
\hline Family & 349 & 45.2 \\
\hline Friends & 134 & 17.4 \\
\hline Family and Friends & 235 & 30.4 \\
\hline Organized group & 5 & 0.6 \\
\hline Other & 2 & 0.3 \\
\hline
\end{tabular}

Visitors were also asked to share details concerning the frequency with which they recreated at Diamond Lake, as well as other sites (Table 5). Two-thirds of respondents (66.7\%) identified themselves as return visitors and the average year of their first visit was 1988 (mean = 1987.85), twenty-four years earlier. As a whole, visitors reported that they typically visited Diamond Lake nine times per year (mean $=9.30)$ and went to other lakes or forests fifteen times per year $($ mean $=14.80)$. The large majority of visitors $(84.7 \%)$ were on overnight trips while only $15.3 \%$ were on a day trips. Of those on overnight trips, the average length of stay reported was 5.66 days, while those on day trips reported that they typically stayed 6.75 hours during their trip. 
Table 5. Trip Characteristics

\begin{tabular}{|c|c|c|}
\hline 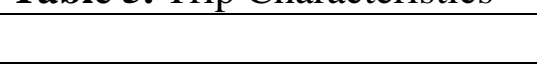 & Frequency & Percent \\
\hline \multicolumn{3}{|l|}{ First visit to Diamond Lake? } \\
\hline Yes & 257 & 33.3 \\
\hline No & 515 & 66.7 \\
\hline Mean year of first visit & 512 & 1987.85 \\
\hline \multicolumn{3}{|l|}{ Days recreating per year } \\
\hline At Diamond Lake & 515 & 9.30 \\
\hline At other Forests & 770 & 14.80 \\
\hline \multicolumn{3}{|l|}{ Trip type } \\
\hline Day trip & 118 & 15.3 \\
\hline Overnight trip & 654 & 84.7 \\
\hline \multicolumn{3}{|l|}{ Length of trip } \\
\hline Mean hours (if day trip) & 118 & 6.75 \\
\hline Mean days (if overnight trip) & 654 & 5.66 \\
\hline
\end{tabular}

The last aspect of visitor characteristics they were asked to respond to concerned the activities that they engaged in during their stay at Diamond Lake (Table 6). Visitors were first asked to list all the activities that they participated in over the course of their stay and then identify one activity as their primary activity during their stay. Results revealed that popular activities at Diamond Lake included fishing (74.1\%), camping in developed sites (66.1\%), general activities like relaxing and hanging out (63.0\%), viewing natural features (54.3\%). Other activities like hiking or walking (40.2\%), motorized water travel (35.1\%), and picnicking or family gatherings in developed sites (33.5\%) were also common among visitors. Relatively few visitors engaged in activities like non-motorized water travel (9.3\%), backpacking or camping in unroaded areas (3.4\%), or horseback riding (2.5\%) around the Lake. In the same way, nearly half of the visitors $(49.2 \%)$ listed fishing as their primary activity at Diamond Lake. Camping in developed sites was the only other primary activity which represented a major segment of visitors (26.4\%); every other primary activity represented less than $10 \%$ of the overall sample. 
Table 6. Activity Participation

\begin{tabular}{|c|c|c|c|c|}
\hline & \multicolumn{2}{|c|}{ Activity Participation } & \multicolumn{2}{|c|}{ Primary Activity } \\
\hline & Frequency & Percent & Frequency & Percent \\
\hline \multicolumn{5}{|l|}{ Activity } \\
\hline Fishing- all types & 572 & 74.1 & 380 & 49.2 \\
\hline Camping in developed sites & 510 & 66.1 & 204 & 26.4 \\
\hline $\begin{array}{l}\text { General/other- relaxing } \\
\text { hanging out, escaping heat, } \\
\text { noise, etc. }\end{array}$ & 486 & 63.0 & 70 & 9.1 \\
\hline $\begin{array}{l}\text { Picnicking and family } \\
\text { gatherings in developed sites }\end{array}$ & 259 & 33.5 & 22 & 2.8 \\
\hline Primitive camping & 82 & 10.6 & 16 & 2.1 \\
\hline $\begin{array}{l}\text { Viewing natural features } \\
\text { (scenery/wildlife/etc.) }\end{array}$ & 419 & 54.3 & 14 & 1.8 \\
\hline Resorts and cabins & 111 & 14.4 & 11 & 1.4 \\
\hline Bicycling/Mtn. biking & 189 & 24.5 & 15 & 1.9 \\
\hline Hiking or walking & 310 & 40.2 & 10 & 1.3 \\
\hline Non-motorized water travel & 72 & 9.3 & 10 & 1.3 \\
\hline Motorized water travel & 271 & 35.1 & 6 & 0.8 \\
\hline $\begin{array}{l}\text { Backpacking, camping in } \\
\text { unroaded areas }\end{array}$ & 26 & 3.4 & 5 & 0.6 \\
\hline Swimming & 144 & 18.7 & 4 & 0.5 \\
\hline Other & 6 & 0.8 & 3 & 0.4 \\
\hline Driving for pleasure on roads & 153 & 19.8 & 1 & 0.1 \\
\hline Horseback riding & 19 & 2.5 & 1 & 0.1 \\
\hline
\end{tabular}

*Note: Ordered from highest to lowest percentage for primary activity 


\section{R2: What is the level of satisfaction among recreation users?}

As part of the survey, visitors were asked a battery of questions regarding their feelings of satisfaction with their visit to Diamond Lake. Respondents were first asked to rate their overall level of satisfaction (Table 7). The average satisfaction level indicated by respondents was 8.65 on a scale of 1 to 10 , with 1 being "very unsatisfied" and 10 being "very satisfied." Additionally, only $6.2 \%$ rated their level of satisfaction as 5 or lower, compared to $44.0 \%$ who rated their level of satisfaction as a 10 .

Table 7. Level of Satisfaction

\begin{tabular}{|c|c|c|}
\hline \multicolumn{2}{|c|}{ Frequency } & Percent \\
\hline Overall satisfaction & 2 & 0.3 \\
\hline 1 & 7 & 0.9 \\
\hline 2 & 11 & 1.4 \\
\hline 3 & 8 & 1.0 \\
\hline 4 & 20 & 2.6 \\
\hline 5 & 23 & 3.0 \\
\hline 6 & 52 & 6.7 \\
\hline 7 & 184 & 23.8 \\
\hline 8 & 125 & 16.2 \\
\hline 9 & 340 & 44.0 \\
\hline 10 & \multicolumn{2}{|c|}{} \\
\hline \multicolumn{2}{|c|}{8.65} \\
\hline Mean level of satisfaction &
\end{tabular}

*Note: Answers were on a scale of 1-10, 1 being "very unsatisfied" and 10 being "very satisfied."

As already alluded to, respondents were asked to share their level of agreement with four statements regarding their satisfaction (Table 8). "I thoroughly enjoyed my visit to this lake," was the first statement and was one that respondents largely affirmed. On a scale of 1 to 5 , where 1 was "strongly disagree" and 5 was "strongly agree," nearly two thirds of the visitors (64.9\%) said that they strongly agreed with this statement and the overall mean score was 4.57 . When asked if "this trip was well worth the money I spent to take it," respondents again indicated a high level of agreement for the most part. The average response for this statement was 4.42 and 
well over half (56.7\%) expressed that they strongly agreed. Visitors predominantly disagreed with the next statement, "I was disappointed with some aspects of my visit to Diamond Lake." On the 1 to 5 scale, the average response was 2.10 and the majority of respondents indicated that they either "disagreed" $(29.4 \%)$ or "strongly disagreed" $(39.9 \%)$. The final statement was "the other people at the lake increased my enjoyment. Unlike any of the other statements, responses were largely mixed or neutral among visitors. The average response was 3.22 and $43.5 \%$ of the visitors said they were neutral.

Table 8. Level of Agreement with Satisfaction Statements

\begin{tabular}{|l|c|c|c|c|c|c|}
\hline & & & & & & \\
\hline \begin{tabular}{c} 
"I thoroughly enjoyed my visit to the Lake" \\
\hline $\begin{array}{c}\text { "This trip was well worth the money I spent } \\
\text { to take it" }\end{array}$
\end{tabular} & $0.3 \%$ & $0.9 \%$ & $5.1 \%$ & $28.9 \%$ & $64.9 \%$ & 4.57 \\
\hline $\begin{array}{c}\text { "I was disappointed with some aspects of } \\
\text { my visit to Diamond Lake" }\end{array}$ & $39.9 \%$ & $29.4 \%$ & $14.8 \%$ & $12.4 \%$ & $3.5 \%$ & 2.10 \\
\hline $\begin{array}{c}\text { "The other people at the lake increased my } \\
\text { enjoyment" }\end{array}$ & $6.6 \%$ & $13.9 \%$ & $43.5 \%$ & $22.9 \%$ & $13.1 \%$ & 3.22 \\
\hline
\end{tabular}

*Note: Answers were on a scale of 1-5, 1 being "strongly disagree" and 5 being "strongly agree." 


\section{R3: What are users' perceptions of crowding and conflict at the lake?}

Visitors were asked to share the details of their perceptions in relation to crowding and conflict at Diamond Lake through a variety of questions. They were first asked to evaluate their overall feelings of crowding on a scale of 1 to 9 , where 1 is "not at all crowded" and 10 is “extremely crowded" (Table 9). The most common response (mode) was a 2 with $22.9 \%$ of the overall sample and the average response was 3.29 on the 1 to 9 scale. Generally speaking, the number of responses declined as the crowding scale increased.

Table 9. Level of Crowding

\begin{tabular}{|l|c|c|}
\hline \multicolumn{2}{|c|}{ Frequency } & Percent \\
\hline Feelings of crowding & 175 & 22.7 \\
\hline 1 & 177 & 22.9 \\
\hline 2 & 138 & 17.9 \\
\hline 3 & 74 & 9.6 \\
\hline 4 & 79 & 10.2 \\
\hline 6 & 47 & 6.1 \\
\hline 7 & 48 & 6.2 \\
\hline 8 & 20 & 2.6 \\
\hline 9 & 14 & 1.8 \\
\hline \multicolumn{2}{|c|}{3.29} \\
\hline Mean level of crowding & \multicolumn{2}{|c|}{} \\
\hline
\end{tabular}

*Note: Answers were on a scale of 1-9, 1 being "not at all crowded" and 10 being "extremely crowded."

As a factor in crowding, visitors were next asked to identify the percentage of time they were in sight of other groups and then the corresponding percentage of time that they actually considered to be acceptable (Table 10). Respondents gave their answers on a scale of 1 to 11 , where 1 meant 0 percent of the time and 11 meant 100 percent of the time. On this scale, the mean percentage of time that respondents said they were in sight of other groups was $83.2 \%$. On average, however, they said that $79.3 \%$ was an acceptable percentage of time to be within sight of other groups. As indicated by visitors, this reflected a gap of nearly $4 \%$ between the acceptable and actual amounts of time in sight of other groups. 
Table 10. Time in Sight of Other Groups

\begin{tabular}{|l|c|}
\hline & Mean \\
\hline Percentage of time in sight of other groups & 83.2 \\
\hline Acceptable percentage of time to be in sight of other groups & 79.3 \\
\hline
\end{tabular}

In a related question, respondents were specifically asked to compare the number of people they saw in relation to how many they expected to see (Table 11). Over half of those interviewed $(50.6 \%)$ said that they saw about as many as they had expected to see. About a third $(32.5 \%)$ said they saw either a little less or a lot less than they had expected to see. In comparison, only $11.1 \%$ said they saw a little more or a lot more than they had expected to see. An additional 5.7\%, said they had no expectations.

Table 11. Expectation of Crowding

\begin{tabular}{|c|c|c|}
\hline & Frequency & Percent \\
\hline \multicolumn{3}{|c|}{ Number of people seen vs. number expected } \\
\hline A lot less than you expected & 94 & 12.2 \\
\hline A little less than you expected & 157 & 20.3 \\
\hline About what you expected & 391 & 50.6 \\
\hline A little more than you expected & 64 & 8.3 \\
\hline A lot more than expected & 22 & 2.8 \\
\hline No expectations & 44 & 5.7 \\
\hline
\end{tabular}

The last set of crowding questions asked respondents to identify their level of agreement with several statements (Table 12). The first of these was "I had the opportunity to recreate without feeling crowded." In response, over half of those who responded (52.8\%) said that they strongly agreed and on a scale of 1 to 5 where 1 meant strongly disagree and 5 meant strongly agree the average response was 4.40. The next statement was "I avoided some places at the Lake because there were too many people there." The mean response of visitors was 2.22 and just under two-thirds (64.4\%) said that they disagreed or strongly disagreed with the statement. Lastly, respondents were asked how much they agreed with the statement, "The number of 
people at the Lake reduced my enjoyment." For the most part, visitors generally did not agree with this statement; the average response was 2.16 and two-thirds of those interviewed (66.5\%) said that they either disagreed or strongly disagreed.

Table 12. Level of Agreement with Crowding Statements

\begin{tabular}{|c|c|c|c|c|c|c|}
\hline & 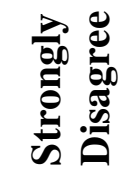 & 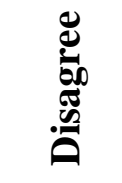 & $\begin{array}{l}\bar{T} \\
\bar{E} \\
\bar{Z}\end{array}$ & 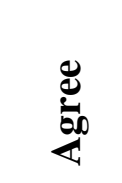 & 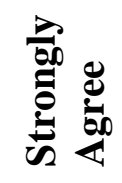 & $\sum_{\Sigma}^{ \pm \pi}$ \\
\hline $\begin{array}{l}\text { "I had the opportunity to recreate without } \\
\text { feeling crowded" }\end{array}$ & $0.1 \%$ & $1.9 \%$ & $8.2 \%$ & $36.9 \%$ & $52.8 \%$ & 4.40 \\
\hline $\begin{array}{l}\text { "I avoided some places at the Lake because } \\
\text { there were too many people there" }\end{array}$ & $37.7 \%$ & $26.7 \%$ & $17.5 \%$ & $12.6 \%$ & $5.6 \%$ & 2.22 \\
\hline $\begin{array}{l}\text { "The number of people at the Lake reduced } \\
\text { enjoyment" }\end{array}$ & $33.2 \%$ & $33.3 \%$ & $21.1 \%$ & $9.6 \%$ & $2.8 \%$ & 2.16 \\
\hline
\end{tabular}

*Note: Answers were on a scale of 1-5, 1 being "strongly disagree" and 5 being "strongly agree."

Visitors were finally asked to indicate their level of agreement with a series of questions relating to whether they had experienced conflict during their time at Diamond Lake, on a scale of 1 to 5 where 1 was strongly disagree and 5 was strongly agree (Table 13). "I could find places to recreate without interference from other visitors," was the first the first of these. Visitors predominantly agreed with this statement. The average response was 4.32 and half of the respondents (49.9\%) said that they strongly agreed. Visitors largely disagreed with the next statement, "Recreation activities at the Lake were not compatible." The large majority (73.5\%) said they disagreed or strongly disagreed while the average among responses was 1.97 . Visitors also mostly disagreed with the last statement, "The behavior of other people at the Lake interfered with the quality of my experience." The average for this statement was 2.08 and over a third (36.1\%) said that they strongly disagreed. 
Table 13. Level of Agreement with Conflict Statements

\begin{tabular}{|c|c|c|c|c|c|c|}
\hline & 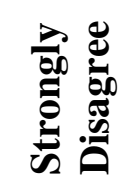 & 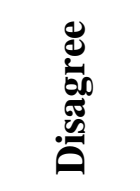 & $\begin{array}{l}\overline{\tilde{J}} \\
\overline{\bar{E}} \\
\bar{z}\end{array}$ & 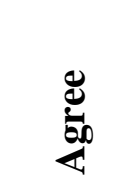 & 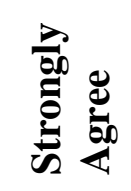 & $\stackrel{\Xi}{\Xi}$ \\
\hline $\begin{array}{l}\text { "I could find places to recreate without } \\
\text { interference from other visitors" }\end{array}$ & $0.5 \%$ & $2.3 \%$ & $11.5 \%$ & $35.8 \%$ & $49.9 \%$ & 4.32 \\
\hline $\begin{array}{l}\text { "Recreation activities at the Lake were NOT } \\
\text { compatible" }\end{array}$ & $43.3 \%$ & $30.2 \%$ & $16.7 \%$ & $6.0 \%$ & $3.9 \%$ & 1.97 \\
\hline $\begin{array}{l}\text { "The behavior of others at the lake interfered } \\
\text { with the quality of my experience" }\end{array}$ & $36.1 \%$ & $34.7 \%$ & $17.9 \%$ & $7.5 \%$ & $3.8 \%$ & 2.08 \\
\hline
\end{tabular}

*Note: Answers were on a scale of 1-5, 1 being "strongly disagree" and 5 being "strongly agree." 


\section{R4: Which items are predictors of user satisfaction at Diamond Lake? Which domain most influences satisfaction: Crowding or conflict?}

While the literature would suggest there is a strong relationship between crowding, conflict and satisfaction; this study reexamines these variables, specifically as it relates to Diamond Lake. Just as previous research has adequately established satisfaction as the litmus test for recreation management success, the following section evaluates just how indicative various items (particularly those relating to crowding and conflict) are of satisfaction.

As already noted, survey items from the past two sections were grouped into three separate domains: satisfaction, crowding, and conflict. Each domain was compared separately and was tested, so as to first evaluate the reliability and level of agreement among items within each domain (Tables 14-19). Negative statements like, "I was disappointed with some aspects of my trip to the lake," were reverse coded on the 5-point Likert scale for comparison to positive statements. It should also be noted that for the purposes of this study and ensuring the integrity of the results, the overall crowding item was excluded from the analysis of research question 4 due to a lack of commonality to other crowding items.

As can be seen in the following set of tables, there were four satisfaction items (excluding overall satisfaction), six crowding items, and three conflict items. The Chronbach's Alpha scores for the three collective domains ranged from as low as 0.530 to as high as 0.557 . This revealed that the items were in fact related and that they were a reliable measure of each domain. 
Table 14. Correlation Matrix for Satisfaction Items

\begin{tabular}{|c|c|c|c|c|}
\hline & 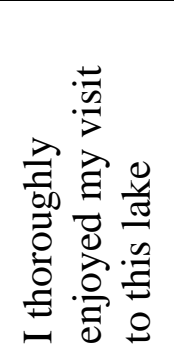 & 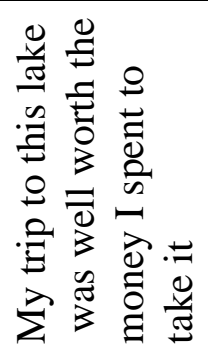 & 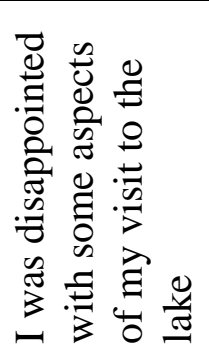 & 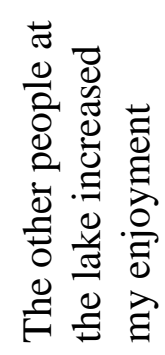 \\
\hline $\begin{array}{l}\text { I thoroughly enjoyed my visit to this } \\
\text { lake }\end{array}$ & 1.000 & & & \\
\hline $\begin{array}{l}\text { My trip to this lake was well worth } \\
\text { the money I spent to take it }\end{array}$ & 0.612 & 1.000 & & \\
\hline $\begin{array}{l}\text { I was disappointed with some aspects } \\
\text { of my visit to the lake }\end{array}$ & 0.391 & 0.343 & 1.000 & \\
\hline $\begin{array}{l}\text { The other people at the lake increased } \\
\text { my enjoyment }\end{array}$ & 0.140 & 0.156 & 0.086 & 1.00 \\
\hline
\end{tabular}

Table 15. Reliability Analysis for Satisfaction Items

\begin{tabular}{|l|c|c|c|c|}
\hline & Item Mean & $\begin{array}{c}\text { Standard } \\
\text { Deviation }\end{array}$ & $\begin{array}{c}\text { Corrected } \\
\text { item-total } \\
\text { correlation }\end{array}$ & $\begin{array}{c}\text { Alpha if } \\
\text { item deleted }\end{array}$ \\
\hline $\begin{array}{l}\text { I thoroughly enjoyed my visit to this } \\
\text { lake }\end{array}$ & 4.57 & 0.657 & 0.530 & 0.394 \\
\hline $\begin{array}{l}\text { My trip to this lake was well worth } \\
\text { the money I spent to take it }\end{array}$ & 4.42 & 0.789 & 0.488 & 0.386 \\
\hline $\begin{array}{l}\text { I was disappointed with some aspects } \\
\text { of my visit to the lake }\end{array}$ & 3.90 & 1.162 & 0.343 & 0.502 \\
\hline $\begin{array}{l}\text { The other people at the lake increased } \\
\text { my enjoyment }\end{array}$ & 3.22 & 1.053 & 0.153 & 0.654 \\
\hline
\end{tabular}

Chronbach's Alpha $=0.557$ 
Table 16. Correlation Matrix for Crowding Items

\begin{tabular}{|c|c|c|c|c|c|c|}
\hline & 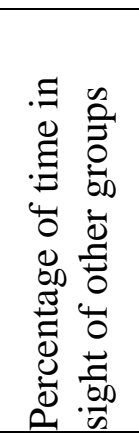 & 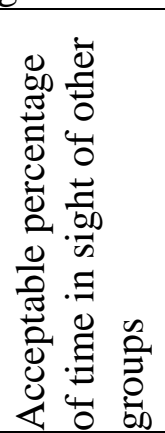 & 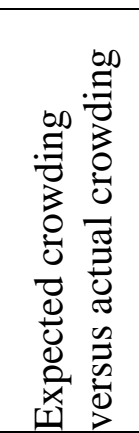 & 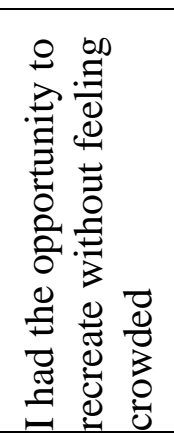 & 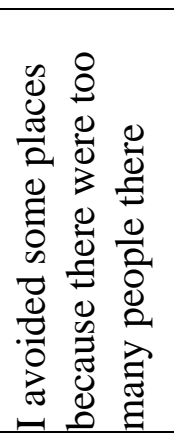 & 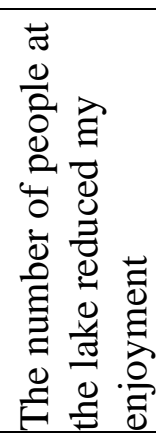 \\
\hline $\begin{array}{l}\text { Percentage of time in sight } \\
\text { of other groups }\end{array}$ & 1.000 & & & & & \\
\hline $\begin{array}{l}\text { Acceptable percentage of } \\
\text { time in sight of other groups }\end{array}$ & 0.642 & 1.000 & & & & \\
\hline $\begin{array}{l}\text { Expected crowding versus } \\
\text { actual crowding }\end{array}$ & 0.060 & 0.006 & 1.00 & & & \\
\hline $\begin{array}{l}\text { I had the opportunity to } \\
\text { recreate without feeling } \\
\text { crowded }\end{array}$ & -0.005 & 0.214 & -0.136 & 1.00 & & \\
\hline $\begin{array}{l}\text { I avoided some places at the } \\
\text { lake because there were too } \\
\text { many people there }\end{array}$ & 0.017 & 0.192 & -0.099 & 0.315 & 1.00 & \\
\hline $\begin{array}{l}\text { The number of people at } \\
\text { the lake reduced my } \\
\text { enjoyment }\end{array}$ & 0.050 & 0.233 & -0.123 & 0.365 & 0.539 & 1.00 \\
\hline
\end{tabular}


Table 17. Reliability Analysis for Crowding Items

\begin{tabular}{|l|c|c|c|c|}
\hline & Item Mean & $\begin{array}{c}\text { Standard } \\
\text { Deviation }\end{array}$ & $\begin{array}{c}\text { Corrected } \\
\text { item-total } \\
\text { correlation }\end{array}$ & $\begin{array}{c}\text { Alpha if } \\
\text { item deleted }\end{array}$ \\
\hline $\begin{array}{l}\text { Percentage of time in sight of other } \\
\text { groups }\end{array}$ & 8.32 & 3.134 & 0.463 & 0.375 \\
\hline $\begin{array}{l}\text { Acceptable percentage of time in } \\
\text { sight of other groups }\end{array}$ & 7.93 & 2.844 & 0.646 & 0.192 \\
\hline $\begin{array}{l}\text { Expected crowding versus actual } \\
\text { crowding }\end{array}$ & 2.86 & 1.176 & -0.024 & 0.577 \\
\hline $\begin{array}{l}\text { I had the opportunity to recreate } \\
\text { without feeling crowded }\end{array}$ & 4.40 & 0.733 & 0.197 & 0.527 \\
\hline $\begin{array}{l}\text { I avoided some places at the lake } \\
\text { because there were too many people } \\
\text { there }\end{array}$ & 2.22 & 2.16 & 0.217 & 0.513 \\
\hline $\begin{array}{l}\text { The number of people at the lake } \\
\text { reduced my enjoyment }\end{array}$ & 2.16 & 1.077 & 0.269 & 0.502 \\
\hline
\end{tabular}

Chronbach's Alpha $=0.530$ 
Table 18. Correlation Matrix for Conflict Items

\begin{tabular}{|c|c|c|c|}
\hline & 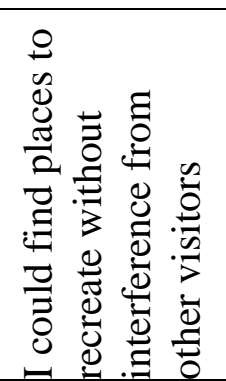 & 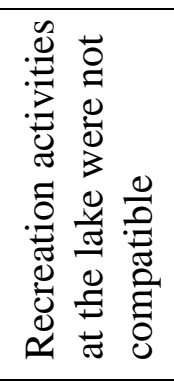 & 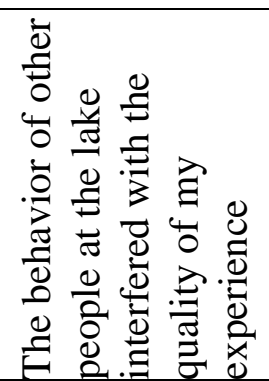 \\
\hline $\begin{array}{l}\text { I could find places to recreate without } \\
\text { interference from other visitors }\end{array}$ & 1.000 & & \\
\hline $\begin{array}{l}\text { Recreation activities at the lake were not } \\
\text { compatible }\end{array}$ & 0.201 & 1.000 & \\
\hline $\begin{array}{l}\text { The behavior of other people at the lake } \\
\text { interfered with the quality of my experience }\end{array}$ & 0.243 & 0.415 & 1.000 \\
\hline
\end{tabular}

Table 19. Reliability Analysis for Conflict Items

\begin{tabular}{|l|c|c|c|c|}
\hline & Item Mean & $\begin{array}{c}\text { Standard } \\
\text { Deviation }\end{array}$ & $\begin{array}{c}\text { Corrected } \\
\text { item-total } \\
\text { correlation }\end{array}$ & $\begin{array}{c}\text { Alpha if } \\
\text { item deleted }\end{array}$ \\
\hline $\begin{array}{l}\text { I could find places to recreate without } \\
\text { interference from other visitors }\end{array}$ & 4.32 & 0.807 & 0.264 & 0.586 \\
\hline $\begin{array}{l}\text { Recreation activities at the lake were } \\
\text { not compatible }\end{array}$ & 4.03 & 1.090 & 0.408 & 0.378 \\
\hline $\begin{array}{l}\text { The behavior of other people at the } \\
\text { lake interfered with the quality of my } \\
\text { experience }\end{array}$ & 3.92 & 1.083 & 0.438 & 0.323 \\
\hline
\end{tabular}

Chronbach's Alpha $=0.553$ 
With the reliability and association between the individual items established within each of the domains, the theoretical relationship to satisfaction was tested next (Tables 20-22). A linear regression model was designed to test the degree to which these domains affect the level of overall satisfaction. Made up of their individual items, the domains of satisfaction, crowding, and conflict were each run with the overall satisfaction serving as the dependent variable in three separate regression analyses.

Satisfaction items were run first and it was found that as a domain, satisfaction items accounted for 17 percent of the variation in overall satisfaction (adjusted $\mathrm{R}^{2}=0.173, \mathrm{~F}$-value $=$ 41.303). Of the four individual satisfaction items, three were found to be statistically valid predictors of overall satisfaction among visitors to Diamond Lake. The statement I thoroughly enjoyed my visit to this lake was most significant and displayed a positive correlation to overall satisfaction $(\mathrm{r}=0.373$, Beta $=0.243, \mathrm{p}<0.001)$. In the same way, the statement $I$ was disappointed with some aspects of my visit to the lake was found to be the next most significant but was negatively correlated to overall satisfaction $(r=-0.304$, Beta $=-0.174, p<0.001)$. Meanwhile, my trip to this lake was well worth the money I spent to take it was only significant at the 0.05 level, but was positively related to the overall satisfaction of visitors $(r=0.305$, Beta $=0.087, \mathrm{p}<0.05)$.

Table 20. Regression Analysis of Satisfaction Items as Indicators of Satisfaction

\begin{tabular}{|l|c|c|}
\hline & r & Beta \\
\hline I thoroughly enjoyed my visit to this lake & $0.373 * * *$ & $0.243^{* * *}$ \\
\hline My trip to this lake was well worth the money I spent to take it & $0.305 * * *$ & $0.087 *$ \\
\hline I was disappointed with some aspects of my visit to the lake & $-0.304 * * *$ & $-0.174 * * *$ \\
\hline The other people at the lake increased my enjoyment & $0.121 * * *$ & 0.058 \\
\hline \multicolumn{2}{|c|}{41.303} \\
\hline F-value & 0.173 \\
\hline Adjusted $\mathrm{R}^{2}$ & \multicolumn{2}{|c|}{} \\
\hline
\end{tabular}

$* \mathrm{p}<0.05, * * \mathrm{p}<0.01, * * * \mathrm{p}<0.001$ 
The results of the crowding domain revealed that the crowding items accounted for nearly 8 percent of the variance in overall satisfaction (adjusted $\mathrm{R}^{2}=0.077$, F-value $=11.768$ ). Of the six items related to crowding, two showed significant results. I had the opportunity to recreate without feeling crowded $(\mathrm{r}=0.249$, Beta $=0.185, \mathrm{p}<0.001)$ was the first significant statement and had a positive correlation to overall satisfaction. The other significant statement, the number of people at the lake reduced my enjoyment $(\mathrm{r}=-0.217$, Beta $=-0.123, \mathrm{p}<0.01)$ displayed a negative correlation to overall satisfaction among visitors. None of the other crowding items exhibited a significant relationship to overall satisfaction.

Table 21. Regression Analysis of Crowding Items as Indicators of Satisfaction

\begin{tabular}{|l|c|c|}
\hline & r & Beta \\
\hline Percentage of time in sight of other groups & 0.050 & 0.007 \\
\hline Acceptable percentage of time in sight of other groups & $0.136 * * *$ & 0.059 \\
\hline Expected crowding versus actual crowding & -0.037 & 0.005 \\
\hline I had the opportunity to recreate without feeling crowded & $0.249 * * *$ & $0.185^{* * *}$ \\
\hline $\begin{array}{l}\text { I avoided some places at the lake because there were too many } \\
\text { people there }\end{array}$ & $-0.159 * * *$ & -0.023 \\
\hline \begin{tabular}{l} 
The number of people at the lake reduced my enjoyment \\
\hline
\end{tabular} & $-0.217 * * *$ & $-0.123 * *$ \\
\hline F-value & \multicolumn{2}{|c|}{11.768} \\
\hline Adjusted $\mathrm{R}^{2}$ & 0.077 \\
\hline
\end{tabular}

$* \mathrm{p}<0.05, * * \mathrm{p}<0.01, * * * \mathrm{p}<0.001$

Conflict was analyzed last in the regression model for its impact on the level of overall satisfaction and accounted for 8 percent of the variance (adjusted $\mathrm{R}^{2}=0.082, \mathrm{~F}$-value $=24.060$ ). There were three conflict items measured and of them, two were significant. The first significant statement, $I$ could find places to recreate without interference from other visitors was positively related to overall satisfaction $(\mathrm{r}=0.222$, Beta $=0.176, \mathrm{p}<0.001)$. The statement recreation activities at the lake were not 
compatible was also significant but was found to have a negative correlation to overall satisfaction $(\mathrm{r}=$ 0.227 , Beta $=-0.172, \mathrm{p}<0.001)$.

Table 22. Regression Analysis of Conflict Items as Indicators of Satisfaction

\begin{tabular}{|l|c|c|}
\hline $\begin{array}{l}\text { I could find places to recreate without interference from other } \\
\text { visitors }\end{array}$ & $0.222^{* * *}$ & $0.176^{* * *}$ \\
\hline Recreation activities at the lake were not compatible & $-0.227^{* * *}$ & $-0.172^{* * * *}$ \\
\hline $\begin{array}{l}\text { The behavior of other people at the lake interfered with the } \\
\text { quality of my experience }\end{array}$ & $-0.163^{* * *}$ & -0.049 \\
\hline & \multicolumn{2}{|c|}{24.060} \\
\hline F-value & 0.082 \\
\hline Adjusted $\mathrm{R}^{2}$ & \multicolumn{2}{|c|}{} \\
\hline
\end{tabular}

$* \mathrm{p}<0.05, * * \mathrm{p}<0.01, * * * \mathrm{p}<0.001$

Based off of the results of this regression analysis, it can be determined that there are 7 items that are predictive of overall satisfaction at Diamond Lake. Of these, three were related to satisfaction, two to crowding, and two to conflict. The model displayed in Figure 1 (Figure 1) was formulated in order to show the way in which each domain and its respective items influence the level of overall satisfaction among visitors to Diamond Lake. 
Figure 2. Relationship of Satisfaction, Crowding, \& Conflict to Overall Satisfaction

\begin{tabular}{|l|l|l|} 
Crowding \\
$\begin{array}{l}\left.\text { (Adjusted } \mathrm{R}^{2}=0.077\right) \\
\text {-I had the opportunity to } \\
\text { recreate without feeling } \\
\text {-The number of people at the } \\
\text { lake reduced my enjoyment }\end{array}$
\end{tabular}




\section{R5: What differences in user perceptions of crowding, conflict and satisfaction exist between locations?}

Just as the previous research question compared visitor characteristics between locations, the following chapter compares the perceptions of users across the same four zones. The three domains already discussed in previous questions (see Research Questions 2, 3, and 4) are again examined. However, the means for each domain are compared from zone to zone. A one way analysis of variance was run where $p<0.05$ with a $95 \%$ confidence interval. The results are displayed separately for the three different domains of crowding, conflict, and satisfaction (see Table 23).

Of the three domains which were comprised of 15 individual items, only crowding had any items which exhibited significant variance across zones. There were no satisfaction items or conflict items identified as being significant. Within crowding however, three items were significant. The first of these was the respondents' overall feelings of crowding $(F=7.314, p<$ 0.001). Visitors in the South $($ mean $=2.98)$ and West $($ mean $=2.83)$ zones reported significantly lower feelings of crowding in other zones. At the same time, visitors to the North zone (mean = 3.78) indicated significantly higher levels of crowding. The next significant item was the percentage of time in sight of other groups $(\mathrm{F}=11.866, \mathrm{p}<0.001)$. Respondents in the South zone $($ mean $=71.9)$ indicated that they spent less time in sight of other groups than those to the North, East, or West. The only other significant item identified was the acceptable percentage of time to be in sight of other groups $(\mathrm{F}=6.302, \mathrm{p}<0.001)$. Visitors to the South zone (mean $=$ 71.9) once again indicated a much lower percentage of time than other visitors. On the other hand, visitors to the East $($ mean $=82.7)$ and West $($ mean $=83.0)$ were willing to spend a significantly greater amount of time in sight of other groups. 
Table 23. Comparison of Crowding, Conflict \& Satisfaction Means Across Survey Locations

\begin{tabular}{|c|c|c|c|c|c|}
\hline & North & East & South & West & \multirow{2}{*}{$\mathbf{F}$} \\
\hline & \multicolumn{4}{|c|}{ Mean } & \\
\hline \multicolumn{6}{|l|}{ Satisfaction Items } \\
\hline Overall satisfaction & 8.65 & 8.79 & 8.47 & 8.66 & 1.216 \\
\hline $\begin{array}{l}\text { I thoroughly enjoyed my visit to this } \\
\text { lake }\end{array}$ & 4.60 & 4.63 & 4.52 & 4.48 & 2.006 \\
\hline $\begin{array}{l}\text { My trip to this lake was well worth } \\
\text { the money I spent to take it }\end{array}$ & 4.43 & 4.40 & 4.41 & 4.47 & 0.197 \\
\hline $\begin{array}{l}\text { I was disappointed with some aspects } \\
\text { of my visit to the lake }\end{array}$ & 2.07 & 2.16 & 2.03 & 2.16 & 0.546 \\
\hline $\begin{array}{l}\text { The other people at the lake } \\
\text { increased my enjoyment }\end{array}$ & 3.28 & 3.28 & 3.13 & 3.11 & 1.391 \\
\hline \multicolumn{6}{|l|}{ Crowding Items } \\
\hline Feelings of crowding & $3.78 b$ & $3.28 \mathrm{ab}$ & $2.98 \mathrm{a}$ & $2.83 a$ & $7.314 * * *$ \\
\hline $\begin{array}{l}\text { Percent of time in sight of other } \\
\text { groups }\end{array}$ & $85.3 b$ & $87.1 b$ & $71.9 \mathrm{a}$ & $89.6 b$ & $11.866^{* * * *}$ \\
\hline $\begin{array}{l}\text { Acceptable percent of time to be } \\
\text { in sight of other groups }\end{array}$ & $80.0 \mathrm{ab}$ & $82.7 b$ & $71.9 \mathrm{a}$ & $83.0 \mathrm{~b}$ & $6.302 * * *$ \\
\hline Number seen vs. number expected & 2.74 & 2.70 & 2.62 & 2.57 & 1.009 \\
\hline $\begin{array}{l}\text { I had the opportunity to recreate } \\
\text { without feeling crowded }\end{array}$ & 4.43 & 4.41 & 4.44 & 4.28 & 1.249 \\
\hline $\begin{array}{l}\text { I avoided some places because there } \\
\text { were too many people there }\end{array}$ & 2.23 & 2.21 & 2.18 & 2.26 & 0.127 \\
\hline $\begin{array}{l}\text { The number of people at the lake } \\
\text { reduced my enjoyment }\end{array}$ & 2.19 & 2.17 & 2.14 & 2.07 & 0.302 \\
\hline \multicolumn{6}{|l|}{ Conflict Items } \\
\hline $\begin{array}{l}\text { I could find places to recreate } \\
\text { without interference from others }\end{array}$ & 4.31 & 4.34 & 4.34 & 4.28 & 0.175 \\
\hline $\begin{array}{l}\text { Recreation activities at the lake } \\
\text { were not compatible }\end{array}$ & 2.07 & 1.89 & 1.98 & 1.93 & 1.145 \\
\hline $\begin{array}{l}\text { The behavior of others interfered } \\
\text { with the quality of my experience }\end{array}$ & 2.04 & 2.08 & 2.10 & 2.14 & 0.254 \\
\hline
\end{tabular}

Note: Scheffe's post hoc analysis test, where $\mathrm{a}<\mathrm{b}$

$* \mathrm{p}<0.05, * * \mathrm{p}<0.01, * * * \mathrm{p}<0.001$ 


\section{CHAPTER 5 \\ DISCUSSION \& CONCLUSIONS}

This chapter builds upon the previous chapters by elaborating on the results that were reported. The individual research questions are discussed and investigated in greater detail through an analysis and comparison to past studies at Diamond Lake and related outdoor recreation research. These results are meant to provide useful suggestions to Forest managers and thereby by improve conditions at Diamond Lake. Consequently, this chapter also includes an assessment of the study's results and the subsequent implications for managers on the Umpqua National Forest, as well as the larger field of study.

As previously discussed, this research and findings of this particular thesis were conducted as part of a larger assessment of conditions within the Umpqua National Forest. Data was collected via face-to-face interviews were conducted on-site by interviewers through the months of June, July, and August around Diamond Lake. This study primarily utilized an iPad survey instrument, as well as paper instruments which were later entered into the iPads for uploading data.

As already mentioned, four distinct zones (North, South, East, \& West) were identified around Diamond Lake for the sake of comparison. Of the four, more surveys were collected in the East zone (256) than in any other. In contrast, the second highest number of surveys was collected in the North Zone (256). The South zone (188) and the West zone (107) both had the least amount of responses. These frequencies were relatively unsurprising in relation to the amount of development within each of these zones. For example, the North zone contains the Diamond Lake Resort and the East zone is the location of Diamond Lake Campground, which are traditionally the two highest-use areas around the Lake (Gaydos, 2008). 


\section{R1: What are the characteristics of recreation users?}

In order to evaluate the characteristics of the recreationists at Diamond Lake, Oregon numerous questions were asked regarding their socio-demographics, trip and group characteristics. Results revealed that the sample consisted mostly of males (59.2\%) compared to females $(40.8 \%)$. The average age of visitors to the Lake was exactly 48 years old and nearly half were over the age of $50(47.1 \%)$. There were very few respondents who weren't U.S. citizens (2.5\%). Just over half reported having a Bachelor's degree or higher (52.6\%) and making between $\$ 50,000$ and $\$ 150,000$ per year (58.5\%). Meanwhile, the vast majority of respondents were white/Caucasian (97.4\%); there were also portions of American Indian or Alaska Native (3.8\%), Black or African American (2.0\%), and Japanese (1.6\%) present as well. Only $3.1 \%$ of the sample identified themselves of being Hispanic, Latino, or Spanish in origin. These results point towards a "typical" Diamond Lake being an older, white, male who is moderately well-educated, probably holding at least a Bachelor's degree and making between fifty and ninety-nine thousand dollars per year.

Most of the respondents were return visitors (66.7\%) and on average had been coming to Diamond Lake since 1988 (mean year $=1987.85)$. At the same time, they typically spent more time in other forests (mean $=14.80$ days) than at Diamond Lake (mean $=9.30$ days) in a given year. More visitors were on overnight trips at the Lake (84.7\%) than day trips (15.3\%). Those staying overnight typically stayed for six days (mean $=5.66)$ while those staying overnight were there for 7 hours on average (mean $=6.75$ ). In regard to their activities, many visitors participated in fishing $(74.2 \%)$, camping $(66.1 \%)$, general (63.0\%), viewing natural features (54.3\%), and hiking or walking (40.2\%). When asked to identify their primary activity, most said that they were either fishing (49.2\%) or camping (26.4\%). Visitors typically were on overnight 
trips at the Lake. This suggests that the average visitor will have been coming to Diamond Lake for nearly twenty-five years and while they may spend a greater amount of combined time at other forests, they typically spend numerous days at Diamond Lake each year. While they may participate in numerous outdoor activities, they primarily come to Diamond Lake to spend several days fishing and camping overnight, reinforcing the notion that Diamond Lake is first and foremost an angling destination.

As far as the makeup of visitor groups, nearly half reported that they were with family (45.2\%). Another large portion said they were with family and friends (30.4\%) or with friends (17.4\%). To further understand the composition of these groups, it was determined that they typically consisted of four adults $($ mean $=4.40)$ and 1 child $($ mean $=1.48)$. On average, each group would also have two cars, trucks, or motorcycles $($ mean $=2.06)$, one RV $($ mean $=0.56)$, and one trailer $($ mean $=0.91)$. From these results, we can infer that groups were typically made up of five family-members, one of which would be a child. Likewise, they would have some sort of RV, but would also have two vehicles and trailer, which presumably would be used to tow their boat for fishing.

\section{R2: What is the level of satisfaction among recreation users?}

Satisfaction is one of the most important indicators of management success regarding a site's social conditions (Burns, 2000; Manning, 2011). As this study sought to evaluate conditions around Diamond Lake, there were several scales and related questions used to evaluate the level of satisfaction among visitors. The first of these asked visitors to share their overall level of satisfaction regarding their experience at the Lake. This was on a scale of one to ten, with one being "very unsatisfied" and ten being "very satisfied." It was found that the average level of satisfaction 8.65 and the distribution of 
answers was heavily towards the ten end of the scale $(8$ and over $=84.0 \%)$. This would suggest that overall satisfaction is very high among visitors to Diamond Lake.

The second and final set of satisfaction questions were on a 5-point Likert scale with one being “strongly disagree," five being "strongly agree," and three being “neutral.” The respondents were asked to respond accordingly to two positive statements and one negative one. Respondents indicated that they generally disagreed when asked if they were disappointed with some aspects of their visit to Diamond Lake (mean = 2.10) and strongly agreed when asked whether the trip was well worth the money they spent to take it $($ mean $=4.42)$. When asked if the other people at the Lake increased their enjoyment $($ mean $=3.22)$, responses were less definitive; most responses were neutral $(43.5 \%)$. However, these statements too lend credence to the notion that visitors are generally very satisfied with their experience at Diamond Lake.

\section{R3: What are users' perceptions of crowding and conflict at the lake?}

Like satisfaction, crowding and conflict are important measures of social conditions at a given site and are inter-related, as they can contribute to or detract from a visitor's feelings of satisfaction (Wagar, 1964; Cole and Hall, 2009; Manning, 2011). Consequently, both crowding and conflict were analyzed as separate domains within this study. Likewise, varying questions and scales were used to ascertain their respective levels.

With the domain of crowding, a scale of one to nine with one being "not at all crowded" and nine being "extremely crowded" was first used to evaluate visitors' general feelings of crowding. It was found that the average response on this scale was 3.29, or "not crowded." In the same way, the distribution of answers was largely towards the low end of the scale. Nearly a quarter responded with a crowding level of one $(22.7 \%)$, compared to only $1.8 \%$ who responded with a nine. 
In the next set of related questions, respondents were first asked to identify the percentage of time that they had spent in sight of other groups while at the lake, which on average was $83.2 \%$ of the time. Similarly, they were asked to identify an acceptable percentage of time to be in sight of other groups. The average visitor response was found to be $79.3 \%$. When these two values were compared, a gap between acceptable time and actual time in sight of other groups was identified. However, at a difference of only $3.9 \%$, this is hardly definitive. This would lead to the conclusion that as a whole, visitors were in sight of other visitors more than they would consider to be reasonable and consequently, some crowding does exist. In a related question visitors were asked how the number of people they saw compared to the number they expected to see. Just over half said that they saw about what they expected to see $(50.6 \%)$. Interestingly, only a combined $11.1 \%$ said there were more or a lot more people than they expected, compared to $32.5 \%$ who said there was less or a lot less than expected. Consequently, it can be inferred that while some crowding may exist at Diamond Lake, there are generally less people there than visitors expected.

Visitors were also asked to reveal their level of agreement with three statements which were a on a scale of one to five with one being "strongly disagree," five being "strongly agree," and three being "neutral." The first was I had the opportunity to recreate without feeling crowded, which was a positive statement and one that the visitors said they agreed with for the most part $($ mean $=4.40)$. In contrast, the other two statements were negative; these were I avoided some places at the Lake because there were too many people there $($ mean $=2.22)$ and the number of people at the Lake reduced my enjoyment (mean $=2.16$ ). Visitors typically disagreed with these statements. These measures and the overall level of crowding reported by respondents again, lead to the conclusion that though crowding is relatively low at Diamond Lake, a small amount does exist. 
With conflict in mind, another set of three question-statements were used to evaluate the level of conflict at Diamond Lake. Once again, these were measured on a 5-point Likert scale with one being “strongly disagree," five being "strongly agree," and three being "neutral." For the positive statement, I could find places to recreate without interference from other visitors respondents typically agreed (mean =4.32). The next two were negative statements. The first was recreation activities at the Lake were not compatible and the responses were decidedly in disagreement with this statement (mean $=1.97)$. Likewise, when asked whether the behavior of other people at the Lake interfered with the quality of my experience, the respondents generally said that they disagreed (mean $=2.08)$. From these results, it can be concluded that very few visitors were experiencing goal interference and that conflict around Diamond Lake was rare. In the same way, the recreation activities visitors were participating in did not conflict with or detract from the activities of others.

\section{R4: Which items are predictors of user satisfaction at Diamond Lake? Which domain most influences satisfaction: Crowding or conflict?}

With crowding, conflict, and satisfaction at Diamond Lake already examined in its most basic forms, the relationships between these concepts was investigated next. This was done with particular consideration for how they contribute to and predict the overall satisfaction of visitors. To do this, the items within each conceptual domain were tested for reliability in three separate correlation matrices. The results revealed that the Chronbachs's Alpha score for each of these domains was between 0.530 and 0.557 .

Subsequently, a linear regression model was run for each domain with the individual items serving as the independent variables against the dependent variable, which was overall satisfaction. The first domain run was satisfaction and of the four items included in the test, three 
were found to be significant. These included, I thoroughly enjoyed my trip to this lake $(\mathrm{r}=0.373$, Beta $=0.243, \mathrm{p}<0.001)$, my trip to this lake was well worth the money spent to take it $(\mathrm{r}=0.305$, Beta $=0.087, \mathrm{p}<0.05)$, and I was disappointed with some aspects of my trip to the lake $(\mathrm{r}=-$ 0.304, Beta $=-0.174, \mathrm{p}<0.001)$. Collectively, it was also determined that satisfaction items accounted for about $17 \%$ of the variance in overall satisfaction (adjusted $\mathrm{R}^{2}=0.173, \mathrm{~F}$-value $=$ 41.303). Unsurprisingly, this supports the idea that satisfaction items are indicative of the overall satisfaction level among visitors to Diamond Lake.

A regression analysis of crowding was also conducted. Six items were tested and two were found to have a statistically significant correlation with overall satisfaction. The two statement were I had the opportunity to recreate without feeling crowded $(\mathrm{r}=0.249$, Beta $=$ $0.185, \mathrm{p}<0.001)$ and the number of people at the lake reduced my enjoyment $(\mathrm{r}=-0.217$, Beta $=$ $-0.123, \mathrm{p}<0.01)$. Similarly, crowding was shown to account for nearly $8 \%$ of the variance in overall satisfaction (adjusted $\mathrm{R}^{2}=0.077, \mathrm{~F}$-value $=11.768$ ). Although these items didn't have as strong of a relationship with overall satisfaction as the satisfaction items, they too were related and specific items were found to be useful in predicting the overall satisfaction of lake visitors.

The regression analysis of conflict at Diamond Lake tested three items and found that two were statistically significant indicators of overall satisfaction. These two statements were I could find places to recreate without interference from other visitors $(\mathrm{r}=0.222$, Beta $=0.176, \mathrm{p}<$ $0.001)$ and recreation activities at the lake were not compatible $(\mathrm{r}=-0.227$, Beta $=-0.172, \mathrm{p}<$ 0.001). It was revealed that conflict was responsible for over $8 \%$ of the variance in overall satisfaction. Therefore it can be inferred that while conflict, like crowding, doesn't contribute as much to overall satisfaction as the items within the satisfaction domain, it is in fact a minor indicator of satisfaction. In the same way, when the results of the crowding and conflict items are 
compared, it is reasonable to suggest that while conflict and crowding are related and share a correlation with overall satisfaction, conflict is a slightly stronger indicator within the context of Diamond Lake.

\section{R5: What differences in user perceptions of crowding, conflict and satisfaction exist between locations?}

Much like the comparison of visitor characteristics, the domains of crowding, conflict and satisfaction were compared across the four zones designated around the Lake. Once again a one-way analysis of variance was used to identify the major differences in these conceptual domains between each zone. The three domains were analyzed as separate constructs.

There was a total of fifteen crowding, conflict, and satisfaction items that were examined. Only three of those items demonstrated significant variance according to location. These three items all fell within the crowding domain; there was no significant variance among the conflict and satisfaction items. The first of these three crowding items was visitors' overall feelings of crowding $(\mathrm{F}=7.314, \mathrm{p}<0.001)$. It was established that perceptions of crowding were lowest among visitors to the South $($ mean $=2.98)$ and West zones $($ mean $=2.83)$, while they were higher in the North zone (mean $=3.78)$. Next, the percentage of time in sight of other groups was found to be a significant item $(\mathrm{F}=11.866, \mathrm{p}<0.001)$. The visitors to the South zone reported being in sight of other groups a much lower percentage of time (mean $=71.9 \%$ ) than any of the other zones. The only other item with significant variance was the acceptable percentage of time to be in sight of other groups $(F=6.302, \mathrm{p}<0.001)$. Respondents within the South zone typically reported a much lower percentage of time as being acceptable (mean $=71.9 \%)$. Visitors 
to the East $($ mean $=82.7 \%)$ and West zones $($ mean $=83.0 \%)$ however, were generally more willing to see other groups.

As a whole, it can be concluded that visitors' feelings of satisfaction and conflict are constant around the lake. Yet, their perceptions of crowding do differ depending on where they are. Visitors to the South zone tended to experience crowding the least and also were generally more accepting of interactions with other groups. On the other hand, visitors in the North zone typically perceived a greater amount of crowding. Though they reported being in sight of other groups for less time than those to the East and West, they were less accommodating of these interactions, which might explain these feelings of crowding. Visitors in the East and West zones spent the greatest amount of time in sight of other groups. They experienced feelings of crowding to varying degrees, but were generally more willing to tolerate these interactions.

\section{$\underline{\text { Discussion }}$}

The primary purpose of this study was to evaluate conditions around Diamond Lake, more specifically the key conceptual domains of crowding, conflict, and satisfaction. While these have been examined and compared in a wealth of previous studies and literature (i.e. Bultena \& Klessig, 1969; Burns, 2000; Borrie and Birzell, 2001; Jackson and Wong, 1982; Jacob and Schreyer 1980; Manning, 2003; Schreyer, Lime, and Williams, 1984; Stankey, 1973), this study was designed to provide further

insight into each of these constructs. While these variables have frequently been compared on a "macro" level or for an area as a comprehensive unit (Manning, 2011), this study is unique in that it also provides an examination of the micro-dynamics that can exist within the larger vicinity. Due to the fact that crowding, conflict and satisfaction are inter-related it became important for the comparison to consider all three (Wagar, 1964; Cole and Hall, 2009; Manning, 2011). The results of this study allow for the 
recognition of trends around the lake and between potentially unique areas. In a more practical sense, this study can assist managers in better understanding the dynamics of Diamond Lake and the visitors who recreate there. Because crowding, conflict, and satisfaction are so important to understanding the social conditions that exist in a recreation area (Wagar, 1964; Wagar, 1966; Cole and Hall, 2009;

Manning, 2011), these were emphasized in the course of this study. From this analysis, managers can determine problems which may exist that need to be addressed or strengths which should be emphasized.

With that said, the results of the analysis on user characteristics were relatively predictable when considering Diamond Lake has historically been and was confirmed to be an angling destination (Gaydos, 2008). While many respondents indicated that they participated in camping in developed sites and general relaxing or hanging out, far fewer indicated that these was their primary activities. This would suggest that camping and general activities like relaxing and hanging out are frequently secondary activities at Diamond Lake and complement the primary activity of fishing. Given that the large majority of visitors also indicated that they were staying overnight at the Lake, this seems to be a reasonable conclusion. In much the same way, activities like motorized water travel, viewing natural features, hiking/walking, and picnicking appear to be tertiary activities within this context. This is often the case with lakes and fisheries and as with Armstrong et al.'s study (1999), this also contributes to fact that the visitor population is predominantly made up of middle to older-aged, white males.

This was very similar to the results of Gaydos's study (2008), which identified a majority of males and a relatively higher mean age among recreationists. However, while the population appears to be largely homogenous from a statistical perspective, managers would be wrong to make the assumption that all fisherman and visitors to Diamond Lake are the same (Armstrong et al., 1999; Shafer, 1969). 
Policy in regard to fishing must remain dynamic in order to accommodate a wide and changing spectrum of recreationists (Armstrong et al., 1999).

The results of the crowding analysis revealed that the visitors' perceptions of crowding at Diamond Lake were generally very low, which in itself is not an entirely unexpected finding (Gaydos, 2008). Excluding extreme instances, it is well documented that visitors to recreation sites typically report low levels of crowding despite varying levels of use (Schindler and Shelby, 1995; Anderson et al., 2008). Likewise, they can consciously or sub-consciously employ various coping mechanisms which can account for lower reported levels of crowding (Desor, 1972; Schmidt and Keating, 1979). Results would suggest that this may be the case at Diamond Lake; although minor, a gap was found to exist between the amount of time visitors were in sight of other groups and the amount of time in sight of other groups that they considered to acceptable.

Further analysis of crowding results suggests that a complex set of dynamics exists among visitors in regard to their location. Visitors to the South zone experienced the least amount of crowding and were most accepting of seeing other groups. In comparison, the visitors to the North zone reported the highest level of crowding and were less willing to accommodate these interactions. At first, this would appear to be logical, as the North and East zones are where the largest volume of visitors exists and evidenced by the number of surveys collected. However, upon further inspection it fails to explain the fact that visitors in the East and West reported similarly low levels of crowding and yet also reported being in sight of groups the greatest amount of time.

It is important to remember that the level of crowding that is perceived by visitors is not necessarily dictated by the amount of interactions with other visitors. Rather it can be influenced by a number of variables including, but not limited to visitor's expectations and activity (Manning, 2003). In this case, the author would propose that most of the visitors to these two zones were camping. Therefore 
they were in a context in which they expect to be in sight of others for longer periods of time. Future research which specifically examines the expectations and/or preferences of visitors in campgrounds may provide useful insights in this regard.

As can be inferred from the Gaydos study (2008), crowding as a whole at Diamond Lake is relatively low and has been in recent years. However, results indicate that some crowding does exist at the lake and particularly in the North zone. It should also be noted that while the level of crowding does ultimately have a bearing on satisfaction, it was found to be minimally so within the context of Diamond Lake, Oregon. In a more practical sense, these findings do not necessarily necessitate action of the part of managers as it may be unrealistic to invest valuable resources in minimizing minor issues. As in Schindler and Shelby's study of Rogue River boaters (1995), recreation users will often cope by selfadjusting their expectations in order to accommodate greater numbers fellow recreationists and therefore mitigating the need for management action.

In comparison to crowding, the results of the conflict items revealed nothing remarkable or even unexpected. Conflict was almost nonexistent at Diamond Lake; very few visitors reported any problems or interference from other visitors in achieving their desired outcomes. In the same way, there wasn't any zone at Diamond Lake that displayed a higher prevalence of conflict compared to the others. It was noteworthy though, that conflict as a domain was found to be a slightly stronger indicator of overall satisfaction among visitors than the crowding domain. With only a slightly higher statistical significance however, this is hardly definitive.

Like those under the conflict domain, the results among satisfaction variables were somewhat pedestrian in their implications. Regardless, the mere fact that visitor satisfaction itself is indicative of the overall conditions and management (Wagar, 1966; Lime and Stankey, 1971; Burns, 2000) make this an especially important variable to evaluate. In any case, the level of satisfaction was found to be 
universally high for Diamond Lake and each of the zones surrounding it. All the measures considered as part of this domain were generally unanimous in this conclusion. This finding is consistent with other studies, (Burns, 2000; Chuprinko, 2012; Gaydos, 2008; Mestrovic III, 2011; Shrestha et al., 2008) which often find satisfaction to be high among recreationists. In fact, it is very rare to find low satisfaction among users, a phenomenon which researchers have attributed to several factors. Primarily, it has been suggested that visitors are typically on vacation or off and in an environment where they come to enjoy themselves, thereby making it more likely that they respond favorably to any question regarding the quality of their experience (Graefe \& Fedler, 1986; Manning, 2011). Gaydos's study at Diamond Lake five years prior (2008) reached similar conclusions. While Gaydos (2008) focused on site quality variables and this report emphasizes crowding and conflict items, the results of that study also implied that visitor satisfaction at the Lake was generally very high.

\section{Management Implications}

For the recreation managers at Diamond Lake and the Umpqua National Forest, there are several things to consider in light of these results. This study aimed to evaluate visitor perceptions around the lake, and satisfaction was found to be the most important indicator of overall conditions. Satisfaction among visitors to Diamond Lake was clearly high, suggesting that management has been largely effective in meeting visitor demand. Maintaining this level of satisfaction should be the foremost goal of recreation managers. The results of this study would suggest that there are several ways by which managers can do this and actually improve upon the current conditions.

Continuing to emphasize fishing is imperative to satisfying the visitors to Diamond Lake. As already discussed in this study and confirmed by the work of Gaydos (2008), fishing is the 
primary activity at Diamond Lake. With that in mind, policy should continue to reflect these values and managers should be hesitant to enact changes that would alter or limit use around the Lake. Given that most recreationists at Diamond Lake are repeat visitors, they are typically accustomed to certain standards and would be inclined to be dissatisfied with most changes. In the same way, the quality of fishing must be maintained if visitors are to continue enjoying their fishing experience. Tui chub destroyed the integrity of trout populations in the Lake twice before (Gaydos, 2008) and managers must continue to steps to ensure this doesn't happen again.

Perhaps the most important finding of this study stemmed from the analysis of crowding. Visitors were asked a variety of questions regarding crowding that ranged from their expectations to whether they avoided certain areas due to other visitors. Although initial examination indicated that feelings of crowding were generally low among visitors, it was found that some crowding does exist at Diamond Lake. By and large, visitors indicated that there was a gap between the time the spent in sight of other groups and the amount of time that they considered to be acceptable. This was especially true of the North zone where visitors typically expressed higher feelings of crowding and were less willing to tolerate interaction with other visitors. In fact, this zone was the focus of most crowding concerns. This is important, if only because Diamond Lake Resort is located at the center of this zone. The resort arguably hosts the highest volume of visitors passing through the area. While it is perhaps unfair, many people will base their perception of the entire lake and possibly the National Forest on what they experience there. Because this is such a critical location, any crowding problem here must be addressed.

The author would propose that any additional development or expansion of the facilities offered near the resort would only serve to increase stress on the visitor experience in this area. Crowding already appears to a minor issue here and additional facilities would only encourage a 
higher volume of people to be in the area, which has a direct impact on visitor's perceptions of crowding. At the same time, managers could instead divert any further growth elsewhere. A prime area to consider might be the East zone, where crowding is relatively low and camping is the primary activity. Given the close proximity to the North zone and resort, parking and/or other amenities for day visitors and people passing through might turn attention away from the North zone and thereby reduce crowding in the area.

The other point that should be considered was related to conflict. Conflict and friction between visitors in itself was extremely rare at Diamond Lake. However, conflict was also found to be a minor predictor of the satisfaction among Diamond Lake visitors. In other words, satisfaction was high and conflict was low among visitors, suggesting that those who experienced conflict were more likely to report being less satisfied. As a result, it should be noted that just as maximizing the level of satisfaction is the goal of lake managers, minimizing conflict should continue to be a priority as well. While this study didn't specifically compare conflict across activities, future research on this topic would be particularly interesting, namely between anglers and other water-based activities.

As a whole, satisfaction is high at Diamond Lake but should continue to be an emphasis of recreation management policy there. Correspondingly, visitors' perceptions crowding and conflict were both low as well. These were both confirmed to be influential concepts in determining satisfaction levels. With this in mind, it is important to consider and control the levels of both crowding and conflict to maintain satisfaction levels at Diamond Lake. 


\section{Conclusions}

When considering this study, it should be understood that the concepts evaluated do not merely describe the isolated perspectives of visitors. Rather they provide both managers and researchers with a unique look at recreation activity around Diamond Lake and the impact it has on visitors there. Perhaps even more importantly, they allow for the recognition of significant trends and conditions which allow for proactive management practices and a broadening of the recreation research field.

This study evaluated and compared crowding, conflict, and satisfaction; three concepts which are important in determining said conditions. Generally speaking, it was found that satisfaction was high and both crowding and conflict were low. Though these results indicate that recreation around the lake is healthy from a social perspective, the study also highlights several ways that managers can improve conditions. As mentioned in the last section, limiting growth near the resort and diverting traffic away from this area may lower the feelings of crowding and conflict visitors experience here. By managing and limiting the levels of crowding and conflict at the lake, it can be expected that visitor satisfaction will only increase, which is of particular interest to managers. In the same way, these variables must be continually monitored, as conditions around the lake may change in the future.

The findings of this study were consistent with previous research and literature, but were also enlightening in the sense that they offer an insight into the social dynamics which exist around the lake and between the zones therein. As had already been discussed in previous discussion, few studies involving crowding, conflict and satisfaction have examined recreation areas beyond a single spatial unit. In contrast, this study offers a unique look at these concepts 
for both the whole lake and the locations surrounding it. For example, this allowed for the identification of the distinctly different crowding conditions in the North zone.

Further research is needed. There are still questions regarding the degree to which visitors are feeling crowding and how they are coping and adapting to these conditions. As was alluded to, it was difficult to discern whether low crowding conditions identified at certain areas around the lake are actually the result of visitors adjusting their expectations in response to crowding. This would provide an interesting understanding of crowding at Diamond Lake which could even better guide the management there. This would be of particular interest in the East and South zones, where the number of visitors and activity types are different but the levels of crowding are relatively similar. A study which evaluates the levels of crowding at Diamond Lake during times where there are typically fewer visitors present, like autumn, might prove valuable and insightful in this regard.

Overall, this study was successful in demonstrating the relationship between crowding, conflict, and satisfaction and their importance as management principles. Inferences based on the results of this study allow the managers at Diamond Lake to act accordingly and improve the experience of visitors there. This study broadens and contributes to the literature which examines the concepts of crowding, conflict, and satisfaction. 


\section{SURVEY INSTRUMENT}

The Forest Service and West Virginia University are conducting interviews of visitors on the Umpqua National Forest. The information collected will help us better serve our visitors by knowing what activities they do, how long they stay, and how satisfied they are with the facilities and services provided. Your participation is voluntary and all information collected is confidential.

[If more than one person] Which of you had the most recent birthday and is 16 years of age or older?

1. What is the name of the site?

Diamond Lake Resort 28.6\% Diamond Lake Campground 33.2\% South Shore 24.4\% Thielsen View 13.9\%

2. Which area are you recreating at? $\quad \underline{100.0 \%}$ Lake $\quad \underline{0.0 \%}$ River $\quad \underline{0.0 \%}$ Trail

3. Which lake are you recreating at? $\underline{100.0 \%}$ Diamond Lake $\underline{0.0 \%}$ Lemolo Lake

4. We would like to know how satisfied you were with your overall trip to this lake. On a scale of 1-10, with 10 being most satisfied, how satisfied were you with this trip? $\underline{\text { Mean }=8.65}$

5. How crowded did you feel during your visit to this lake? [Please select only $\mathbf{O N E}$ number] $\underline{\text { Mean }=3.29}$

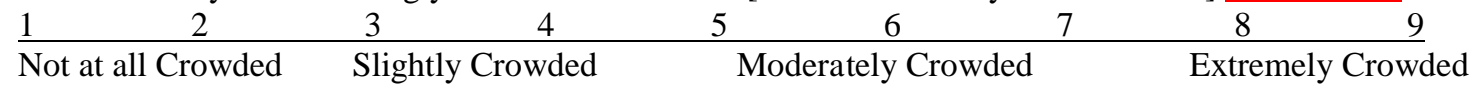

\begin{tabular}{|l|l|c|}
\hline $\begin{array}{l}\text { 6. In what activities on this list did you participate (or } \\
\text { will you participate) during this recreation visit to this } \\
\text { area? [Please select ALL that apply.] }\end{array}$ & $\begin{array}{c}\text { 7. Which of those is your primary activity for } \\
\text { Qhis recreation visit to this area? } \\
\text { [Please } \\
\text { answert ONLY ONE.] }\end{array}$ \\
\hline $\begin{array}{l}\text { Question } 6 \\
\text { answers }\end{array}$ & & $26.4 \%$ \\
\hline & Land-based Activities & $2.1 \%$ \\
\hline $66.1 \%$ & Camping in developed sites (family or group sites) & $0.6 \%$ \\
\hline $10.6 \%$ & Primitive camping (motorized) & $1.4 \%$ \\
\hline $3.4 \%$ & Backpacking, camping in unroaded areas & $2.8 \%$ \\
\hline $14.4 \%$ & Resorts, cabins, and other accommodations on FS managed lands (private or FS) & $1.8 \%$ \\
\hline $33.5 \%$ & Picnicking and family gatherings in developed site (family or group sites) (circle all that apply) \\
\hline $54.3 \%$ & $\begin{array}{l}\text { Viewing natural features such as scenery, wildlife, birds, flowers, fish, etc. (on FS lands) (circle all } \\
\text { that apply) }\end{array}$ & $9.1 \%$ \\
\hline $63.0 \%$ & General/other-relaxing, hanging out, escaping heat, noise, etc. & $0.1 \%$ \\
\hline $19.8 \%$ & Driving for pleasure on roads & $1.3 \%$ \\
\hline $40.2 \%$ & Hiking or walking & $0.1 \%$ \\
\hline $2.5 \%$ & Horseback riding & $1.9 \%$ \\
\hline $24.5 \%$ & Bicycling, including mountain bikes (circle all that apply) & \\
\hline & & $1.3 \%$ \\
\hline & Water-based Activities & $0.8 \%$ \\
\hline $9.3 \%$ & Non-motorized water travel (sailboarding, kayaking, rafting, canoe, etc.) (circle one) & $0.5 \%$ \\
\hline $35.1 \%$ & Motorized water travel (boating, jet skis, etc.) & $49.2 \%$ \\
\hline $18.7 \%$ & Swimming & $0.4 \%$ \\
\hline $74.1 \%$ & Fishing-all types & \\
\hline $0.8 \%$ & Other & \\
\hline
\end{tabular}

8. While you were at the lake today, about what percent of the time were you in sight of other groups?

[Circle ONE number] $\underline{\text { Mean }=83.2 \%}$

$$
\begin{array}{lllllllllll}
0 \% & 10 \% & 20 \% & 30 \% & 40 \% & 50 \% & 60 \% & 70 \% & 80 \% & 90 \% & 100 \% \\
\hline
\end{array}
$$

9. What would be an acceptable percentage of time to see people from other groups while you are at this lake?

[Circle ONE number] Mean $=79.3 \%$

$$
\begin{array}{lllllllllll}
\hline 0 \% & 10 \% & 20 \% & 30 \% & 40 \% & 50 \% & 60 \% & 70 \% & 80 \% & 90 \% & 100 \\
\hline
\end{array}
$$


10. Below is a list of some of the services and facilities provided at this lake. Please tell us how you rate the quality of each of these items on a scale from 1-5, with 1 being strongly disagree and 5 being strongly agree.

\begin{tabular}{|c|c|c|c|c|c|c|}
\hline Quality Attribute & 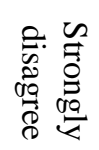 & 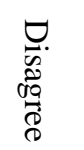 & 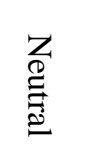 & 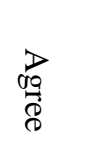 & 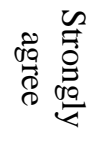 & 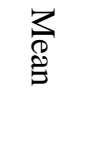 \\
\hline Drinking water is available & 0.6 & 1.0 & 12.7 & 30.1 & 55.6 & 4.39 \\
\hline Recreation use is compatible with the environment & 0.6 & 0.9 & 4.8 & 34.6 & 59.1 & 4.51 \\
\hline Recreation areas are free of animal waste & 0.5 & 2.2 & 6.9 & 35.9 & 54.5 & 4.42 \\
\hline Facilities are in good condition & 0.6 & 1.6 & 8.9 & 37.8 & 51.0 & 4.37 \\
\hline Recreation sites are free of dangerous conditions & 1.9 & 3.4 & 8.8 & 35.8 & 50.1 & 4.29 \\
\hline Facilities are accessible for persons with disabilities or special needs & 1.7 & 3.0 & 8.8 & 35.8 & 50.1 & 3.81 \\
\hline Garbage does not exceed container capacity & 0.9 & 2.5 & 12.8 & 39.0 & 44.0 & 4.24 \\
\hline Uniformed rangers are friendly & 0.5 & 1.0 & 33.1 & 26.2 & 40.2 & 4.04 \\
\hline Views from recreation areas are free of obstruction by buildings or development & 0.3 & 1.0 & 8.5 & 34.3 & 55.8 & 4.44 \\
\hline Roadside signs and directions make recreation sites easy to find & 1.3 & 3.0 & 8.4 & 38.7 & 48.6 & 4.30 \\
\hline Restrooms/Toilets are clean and free of odor & 1.8 & 3.8 & 13.5 & 35.9 & 45.1 & 4.19 \\
\hline Parking spaces are plentiful & 2.2 & 7.5 & 12.2 & 34.6 & 43.5 & 4.10 \\
\hline I feel safe at the recreation areas & 0.3 & 1.3 & 7.8 & 34.1 & 56.6 & 4.45 \\
\hline It is easy to find uniformed Forest Service employees & 6.1 & 10.8 & 31.0 & 28.1 & 24.1 & 3.53 \\
\hline Information boards provide current information & 0.8 & 2.3 & 22.0 & 38.0 & 36.9 & 4.08 \\
\hline Wildlife can be found to observe & 1.0 & 2.7 & 15.0 & 39.9 & 41.3 & 4.18 \\
\hline Roads and trails are in good repair & 0.5 & 1.9 & 9.8 & 42.9 & 44.8 & 4.30 \\
\hline Rules and regulations are clearly posted and easy to understand & 0.8 & 0.9 & 14.1 & 41.7 & 42.5 & 4.24 \\
\hline Fishing is excellent & 4.5 & 9.5 & 32.8 & 25.9 & 27.3 & 3.62 \\
\hline The area is free from litter & 0.6 & 1.9 & 7.6 & 39.1 & 50.6 & 4.37 \\
\hline
\end{tabular}

11. Which of the following best describes the composition of your group? [Please check $\mathbf{O N E}$ ]

6.1\% Alone $\quad \underline{45.2 \%}$ Family $\quad \underline{17.4 \%}$ Friends $\quad \underline{30.4 \%}$ Family \& friends

$0.0 \%$ Commercial group (group of people who paid a fee to participate in this trip)

$\underline{0.6 \%}$ Organized group (club or other organization)

$\underline{0.3 \%}$ Other [please specify]

12. Is this your first visit to this lake? $33.3 \%$ Yes $\underline{66.7 \%}$ No

13. [If NO] In what year did you make your first visit to this lake? Mean $=1988$ year

14. In a typical year, how many days do you spend recreating at this lake? Mean $=9.30$ days

15. In a typical year, how many days do you spend recreating at other lakes? $\underline{\text { Mean }=14.80}$ days

16. Is your trip today... $\underline{84.7 \%}$ an overnight visit to this area $\underline{15.3 \%}$ a day trip [Please check $\mathbf{O N E}$ ]

17. [If overnight] In total, how many days long will this trip be? Mean $=5.66$ days

18. [If daytrip] In total, how many hours will this trip be? Mean $=6.75$ hours

19. How did the number of people you saw during your visit to this lake compare with what you expected to see?

$12.2 \%$ A lot less than you expected

$20.3 \%$ A little less than you expected

$50.6 \%$ About what you expected
$8.3 \%$ A little more than you expected

$2.8 \%$ A lot more than you expected

$\underline{5.7 \%}$ You didn't have any expectations 
20. Which category best describes the experience you think should be provided at this lake?

$6.5 \%$ Wilderness: where solitude is part of the experience

$19.9 \%$ Semi-wilderness: where complete solitude is not expected

$17.5 \%$ Undeveloped recreation: where you expect to see other people some of the time

$46.1 \%$ Scenic recreation: where you expect to see other people much of the time

$10.0 \%$ Social recreation: where seeing many people is part of the experience

21. Overall, how would you rate the quality of each of the following at this lake:

\begin{tabular}{|l|c|c|c|c|c|c|}
\hline & Awful & Fair & Good & Very Good & Excellent & Mean \\
\hline Health and cleanliness & 0.1 & 2.3 & 14.8 & 26.7 & 56.0 & 4.36 \\
\hline Safety and security & 0.3 & 2.2 & 11.9 & 29.6 & 56.1 & 4.39 \\
\hline Condition of facilities & 0.5 & 3.9 & 14.7 & 31.0 & 49.9 & 4.26 \\
\hline Responsiveness of staff & 0.8 & 3.3 & 15.8 & 26.3 & 53.9 & 4.29 \\
\hline Recreation setting & 0.3 & 1.3 & 8.0 & 22.9 & 67.5 & 4.56 \\
\hline
\end{tabular}

22. Here is a list of possible reasons why people recreate at this lake. Please rate each item's importance to you as a reason for recreating at this lake.

\begin{tabular}{|l|c|c|c|c|c|c|}
\hline REASON & $\begin{array}{c}\text { Not at all } \\
\text { Important }\end{array}$ & $\begin{array}{c}\text { Somewhat } \\
\text { Important }\end{array}$ & $\begin{array}{c}\text { Moderately } \\
\text { Important }\end{array}$ & $\begin{array}{c}\text { Very } \\
\text { Important }\end{array}$ & $\begin{array}{c}\text { Extremely } \\
\text { Important }\end{array}$ & Mean \\
\hline To be outdoors & 0.0 & 1.4 & 4.3 & 28.6 & 65.6 & 4.58 \\
\hline For relaxation & 0.1 & 1.3 & 3.8 & 34.6 & 60.2 & 4.53 \\
\hline To get away from the regular routine & 1.2 & 1.3 & 5.9 & 28.5 & 63.1 & 4.51 \\
\hline For the challenge or sport & 11.6 & 11.1 & 20.5 & 25.4 & 31.4 & 3.54 \\
\hline For family recreation & 4.2 & 1.1 & 9.5 & 28.8 & 56.4 & 4.32 \\
\hline For physical exercise & 10.4 & 11.3 & 25.3 & 24.9 & 28.1 & 3.49 \\
\hline To be with my friends & 6.1 & 4.1 & 12.6 & 26.2 & 51.0 & 4.12 \\
\hline To experience natural surroundings & 0.5 & 2.6 & 6.6 & 28.9 & 61.3 & 4.48 \\
\hline To develop my skills & 22.1 & 13.2 & 22.0 & 18.6 & 24.2 & 3.10 \\
\hline
\end{tabular}

23. Which of the following was the most important reason for this visit to this lake? [Check ONE only]

$27.5 \%$ I went there because I enjoy the place itself

$\underline{44.2 \%}$ I went there because it's a good place to do the outdoor activities I enjoy

$\underline{25.9 \%}$ I went there because I wanted to spend more time with my companions

$\underline{2.5 \%}$ I went there because it was close to home

24. What do you like MOST about this lake?

25. What do you like LEAST about this lake?

26. If you could ask resource managers to improve the quality of experience on this lake, what would you ask them to do? 
27. Please look at this list of statements that address your feelings about this trip to this lake. Please indicate your level of agreement with each of the statements listed below.

\begin{tabular}{|c|c|c|c|c|c|c|}
\hline & 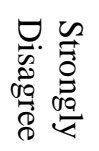 & 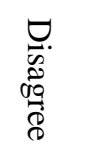 & 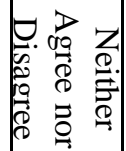 & 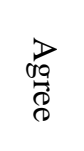 & 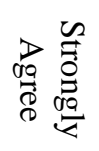 & 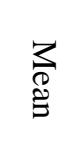 \\
\hline I thoroughly enjoyed my visit to this lake & 0.3 & 0.9 & 5.1 & 28.9 & 64.9 & 4.57 \\
\hline I had the opportunity to recreate without feeling crowded & 0.1 & 1.9 & 8.2 & 36.9 & 52.8 & 4.40 \\
\hline I could find places to recreate without interference from other visitors & 0.5 & 2.3 & 11.5 & 35.8 & 49.9 & 4.32 \\
\hline My trip to this lake was well worth the money I spent to take it & 0.9 & 1.4 & 9.2 & 31.7 & 56.7 & 4.42 \\
\hline Recreation activities at the lake were NOT compatible & 43.3 & 30.2 & 16.7 & 6.0 & 3.9 & 1.97 \\
\hline I was disappointed with some aspects of my visit to the lake & 39.9 & 29.4 & 14.8 & 12.4 & 3.5 & 2.10 \\
\hline I avoided some places at the lake because there were too many people there & 37.7 & 26.7 & 17.5 & 12.6 & 5.6 & 2.22 \\
\hline $\begin{array}{l}\text { There is a good balance between social and biological values in the management of this } \\
\text { lake }\end{array}$ & 2.3 & 2.8 & 22.2 & 39.2 & 33.4 & 3.99 \\
\hline The number of people at the lake reduced my enjoyment & 33.2 & 33.3 & 21.1 & 9.6 & 2.8 & 2.16 \\
\hline $\begin{array}{l}\text { The behavior of other people at the lake interfered with the quality of my experience [if } \\
\text { agree, specify behavior }\end{array}$ & 36.1 & 34.7 & 17.9 & 7.5 & 3.8 & 2.08 \\
\hline The other people at the lake increased my enjoyment & 6.6 & 13.9 & 43.5 & 22.9 & 13.1 & 3.22 \\
\hline The lake and its surroundings are in good condition & 0.9 & 0.8 & 9.7 & 42.6 & 46.0 & 4.32 \\
\hline
\end{tabular}

28. Are you a resident of the United States of America? 97.5\% Yes 2.5\% No

29. [If from US] What is your home ZIP code?

30. [If from other country] Which country are you from?

31. What is your age? Mean $=48.00$ years old

32. What is your gender? $\underline{59.2 \%}$ Male $\quad \underline{40.8 \%}$ Female

33. How many adults are in your group today? Mean $=4.40$ adults

34. How many children (under 18 years) are in your group today? Mean $=1.48$ children up to 17 years

35. How many cars/trucks/motorcycles are in your group today? Mean $=2.06$ cars/trucks/motorcycles

36. How many RV's are in your group today? Mean $=0.56$ RV's

37. How many trailers (any types) are in your group today? Mean $=0.91$ trailers (any type)

38. What is your highest level of education? [Please cirlce $\mathbf{O N E}$ ]

19.9\% High school or less $27.5 \%$ Technical school/ 2 year college $\quad 37.5 \%$ Bachelor's degree $\underline{12.8 \%}$ Master's Degree $\quad \underline{2.3 \%}$ Ph.D./Professional degree

39. What is your annual household income? [Please circle ONE]

$$
\begin{aligned}
& \underline{8.3 \%} \$ 25 \mathrm{k} \text { or less } \quad \underline{14.8 \%} \$ 25 \mathrm{k}-\mathrm{-} \$ 49 \mathrm{k} \quad \underline{40.2 \%} \$ 50 \mathrm{k}-\mathrm{k} \quad \$ 99 \mathrm{k} \quad \underline{18.3 \%} \$ 100 \mathrm{k}-\$ 149 \mathrm{k} \\
& \underline{3.2 \%} \$ 150 \mathrm{k}-\mathrm{\$} \$ 199 \mathrm{k} \quad \underline{2.8 \%} \$ 200 \mathrm{k} \text { or over } \quad \underline{12.4 \%} \text { Don't Know }
\end{aligned}
$$

40. Are you Hispanic, Latino, or Spanish origin? [Please choose ONE] $\underline{3.1 \%}$ Yes $\underline{96.9 \%}$ No

41. With which racial group(s) do you closely identify? [Please choose ALL that apply]
97.4\% White
$2.0 \%$ Black or African American
$\underline{0.7 \%}$ Asian Indian
$1.6 \%$ Japanese
$3.8 \%$ American Indian or Alaska Native
$1.1 \%$ Korean
$0.8 \%$ Filipino
$0.8 \%$ Native Hawaiian
$0.8 \%$ Chinese
$0.4 \%$ Vietnamese
0.7\% Samoan

$1.1 \%$ Other Asian or Pacific Islander 


\section{BIBLIOGRAPHY}

Absher, J. (1998) Customer service measures for National Forest recreation. Journal of Park and Recreation Administration, 16 (3), 31-42.

Adelman, B., Heberlein, T., Bonnicksen, T. (1982). Social psychological explanations for the persistence of a conflict between paddling canoeists and motorcraft users in the Boundary Waters Canoe Area. Leisure Sciences. 5 (1), 45-61.

Anderson, L.E., Manning, R.E., Valliere, W.A. (2008). Indicators and Standards of Quality Across Space and Time, As Reflected in a Study in Acadia National Park, Maine. Proceedings of the 2008 Northeastern Recreation Research Symposium, 130-138.

Armstrong, K.B., MacMahon, P.D. \& Hunt L. (1999). Fish Harvest and Angler Characteristics in the Resource-Based Tourism Industry. NWST Technical Report TR-121. Ontario Ministry of Natural Resources, Northwest Science and Technology.

Borrie, W. T. \& Birzell, R. M. (2001). Approaches to Measuring Quality of the Wilderness Experience. USDA Forest Service Proceedings. RMRS-P-20.

Bultena, G., \& Klessig, L. (1969). Satisfaction in camping: A conceptualization and guide to social research. Journal of Leisure Research, 1, 348-364.

Burns, R.C. (2000). Methodological issues associated with customer satisfaction measurement and market segmentation at water-based recreation areas. Unpublished doctoral dissertation, The Pennsylvania State University.

Cole, D.N., \& Hall, T.E. (2009). Perceived Effects of Setting Attributes on Visitor Experiences in Wilderness: Variation with Situational Context and Visitor Characteristics. Environmental Management, 44, 24-36.

Chuprinko, T.L. (2012). Mountaineering Motivations and Perceived Crowding: An Examination of Climbers on Mt. Baker, Washington and Mt. Hood, Oregon. Master's Thesis. West Virginia University.

Cronin. J., \& Taylor, S. (1992). Measuring quality service: A reexamination and extension. Journal of Marketing, 56, 55-68.

Demir, Z., Muderrisoglu, H., Asikkutlu, H.S., \& Bollukcu, P.A. (2010). Determination of user satisfaction for management practices on recreational areas. African Journal of Agriculural Research, 5 (8), 692-699.

Desor, J. A. (1972). Toward a psychological theory of crowding. Journal of Personality and Social Psychology. 21, 79-83. 
Gaydos, K.R. (2008). An Assessment of Service Quality Indicators as Predictors of Customer Satisfaction at Diamond Lake. Master's Thesis, West Virginia University.

Gibbons, S. \& Ruddell, E. (1995). The effect of goal orientation and place dependence on select goal interferences among winter backcountry users. Leisure Sciences. 17: 171-183.

Government Performance and Results Act of 1993, Public Law 103-62, $103^{\text {rd }}$ Congress (1993).

Graefe, A., and Fedler, A.J. (1986). Situational and subjective determinants of satisfaction in marine recreational fishing. Leisure Sciences, 8 (3), 275-298.

Irland, L. (1975). Citizen Participation-A Tool for Conflict Management on the Public Lands. Public Administration Review, 35 (3), 263-269.

Jackson, E.L., Wong, R.A.G. (1982). Perceived Conflict Between Urban Cross-Country Skiers and Snowmobilers in Alberta. Journal of Leisure Research, 14 (2), 47-62.

Jacob, G.R., \& Schreyer, R. (1980). Conflict in Outdoor Recreation: A Theoretical Perspective. Journal of Leisure Sciences, 12 (4), 368-380.

Kocis, S.M., English, D.M., Zarnoch, S.J., Arnold, R., \& Warren, L. (2003). National visitor use monitoring results: Deschutes National Forest. Report submitted to the USDA Forest Service, Region 6. Southern Research Station.

Kuentzel, W.F., Heberlein, T.A. (1992). Cognitive and Behavioral Adaptations to Perceived Crowding: A Panel Study of Coping and Displacement. Journal of Leisure Research, 24 (4), 377-393.

Lee, J., Graefe, A.R., \& Burns, R.C. (2004). Service quality, satisfaction, and behavioral intention among forest visitors. Journal of Travel and Tourism Marketing, 17(1), 73-82.

Lime, D.W. \& Stankey, G.H. 1971. Carrying capacity: Maintaining outdoor recreation quality. Recreation Symposium Proceedings, Northeast Forest Experiment Station, U.S. Forest Service, USDA. 174-184.

Lohman, G. (2010). Economic and ecological impacts associated with recreation on Colorado Fourteeners. Master's thesis, Colorado State University.

MacKay, K. J., \& Crompton, J. L. (1988). A conceptual model of consumer evaluation of recreation service quality. Leisure Sciences, 7, 41-49.

Manning, R.E., \& Lime, D. (1996). Crowding and carrying capacity in the National Park System: Toward a social science research agenda. Crowding and Congestion in the National Park System: Guidelines for Management and Research. St. Paul: University of Minnesota Agriculture Experiment Station Publication 86, 27-65. 
Manning, R.E. (1999). Crowding and Carrying Capacity in Outdoor Recreation: From Normative Standards to Standards of Quality. Leisure Studies: Prospects for the Twenty-First Century. Ch.19, 323-334.

Manning, R.E. (2003). What to Do About Crowding and Solitude in Parks and Wilderness? A Reply to Stewart and Cole. Journal of Leisure Research, 35 (1), 107-118.

Manning, R.E. (2011). Studies in Outdoor Recreation: Search and Research for Satisfaction ( ${ }^{\text {rd }}$ ed.). Corvallis, OR: Oregon State University Press.

Mestrovic III, A.J. (2011). Wilderness User's Perceptions of Crowding, Satisfaction, Conflict and User Type: Segmentation Study of the Stanislaus National Forest Wilderness Areas. Master's Thesis. West Virginia University.

Multiple Use Sustained Yield Act of 1960, Public Law 86-517, 86th Congress. (1960).

Odum, E. (1959) Fundamentals of Biology. Philadelphia, PA: W.B. Saunders Company.

Oliver, R.L. (1980). A cognitive model of the antecedents and consequences of satisfaction decisions. Journal of Marketing Research, 42, 460-469.

Parasuraman, A., Zeithaml, V.A., \& Berry, L.L. (1985). A conceptual model of service quality and its implications for future research. Journal of Marketing, 49, 41-50.

Parasuraman, A., Zeithaml, V.A., \& Berry, L.L. (1988). SERVQUAL: a multi-item scale for measuring consumer perceptions of service quality. Journal of Retailing, 64(1), 12-40.

Peden, J.G., \& Schuster, R.M. (2008). Assessing the Transactional Nature of Wilderness Experiences: Construct Validation of the Wilderness-Hassles Appraisal Scale. Environmental Management, 42, 497-510.

Schindler, B. \& Shelby, B. (1995). Product shift in recreation settings: Findings and implications from panel research. Leisure Sciences, 17 (2), 91-108.

Schmidt, D.E., \& Keating, J.P. (1979). Human crowding and personal control: An integration of the research. Psychological Bulletin, 86, 680-700.

Schreyer, R., Lime, D.W., Williams, D.R. (1984). Characterizing the influence of past experience on recreation behavior. Journal of Leisure Research, 16 (1), 34-50.

Shafer, E.L. (1969). The Average Camper Who Doesn't Exist. Research Paper NE-142. U.S. Department of Agriculture, Forest Service, NE Forest Experiment Station.

Shrestha, S.K., Burns, R.C., Graefe, A.R., Gaydos, K.R. (2008). Visitors Use Patterns and Satisfaction Along the Rogue-Umpqua Scenic Byway, Oregon. Proceedings of the 2008 Northeastern Recreation Research Symposium. 283-291. 
Stankey, G.H. (1973). Visitor Perception of Wilderness Recreation Carrying Capacity. Research Paper INT-42. U.S. Department of Agriculture, Forest Service, Intermountain Forest and Range Experiment Station.

Stankey, G.H.; Cole, D.N.; Lucas, R.C.; Petersen, M.E.; Frissell, S.S.; Washburne, R.F. (1985). The Limits of Acceptable Change (LAC) system for wilderness planning. Report INT-176. U.S. Department of Agriculture, Forest Service Gen. Tech.

Stokols, D. (1972). On the distinction between density and crowding: Some implications for future research. Psychological Review, 79, 275-9.

USDA Forest Service. (2007). Snowmobiling and the Forest Service. Retrieved on March 3, 2012 from http://www.fs.fed.us/news/2007/speeches/04/snowmobiling.shtml.

USDA Forest Service. (2012). The Umpqua National Forest. Retrieved on March 11, 2012 from http://www.fs.usda.gov/umpqual.

USDI National Park Service. (1993). VERP: a process for addressing visitor carrying capacity in the national park system. Working draft paper. USDI, National Park Service, Denver Service Center, CO.

Vaske, J.J., Donnelly, M.P., \& Heberlein, T.A. (1980). Perceptions of crowding and resource quality by early and more recent visitors. Leisure Sciences, 3(4), 367-381.

Vroom, V.H. (1964). Work and Motivation. New York, NY: McGraw Hill.

Wagar, J.A. (1964). The carrying capacity of wild lands for recreation. Forest Science Monograph 7 , Wahsington, DC: Society of American Foresters.

Wagar, J.A. (1966). Quality in outdoor recreation. Trends in Parks and Recreation, 3 (3), 9-12.

Wagar, J.V. (1946). Services and facilities for forest recreationists. Journal of Forestry, 44, 883-87.

Wang, C.P. \& Chang, Y.H. (2010). How place attachments influence recreation conflict and coping behavior. Proceedings of the Northeastern Recreation Research Symposium, 141-146.

Wang, C.P. \& Dawson, C.P. (2005). Recreation conflict along New York's Great Lakes Coast. Coastal Management. 33: 297-314.

Zeithaml, V.A., \& Bitner, M.J. (1996). Services Marketing. New York, NY: McGraw-Hill. 